\title{
A STUDY TO DETERMINE STUDENT PERCEPTIONS OF \\ THE CAL POL VETERINARY CLINIC
}

\author{
A Thesis \\ Presented to \\ The Faculty of California Polytechnic State University, \\ San Luis Obispo \\ In Partial Fulfillment \\ Of the Requirements for the Degree \\ Master of Science in Agribusiness
}

By

Fallon Bliss Sheridan

July 2014 
(C) 2014

Fallon Bliss Sheridan

ALL RIGHTS RESERVED 


\section{COMMITTEE MEMBERSHIP}

TITLE:

AUTHOR:

DATE SUBMITTED:

COMMITTEE CHAIR:

COMMITTEE MEMBER:

COMMITTEE MEMBER:
A Study to Determine Student Perceptions of the Cal Poly Veterinary Clinic

Fallon Bliss Sheridan

July 2014

Dr. Michael McCullough, Professor, Agricultural Business Department

Dr. Kim Sprayberry, Lecturer, Veterinarian, Animal Science Department

Dr. Eivis Qenani, Professor, Agricultural Business Department 


\section{ABSTRACT}

A Study to Determine Student Perceptions of the Cal Poly Veterinary Clinic.

\section{Fallon Bliss Sheridan}

The purpose of this study was to determine the important benefits of Cal Poly Veterinary Clinic (CPVC) and establish areas of interest for the students at the CPVC. The CPVC is a student run veterinary clinic that exposes students to teachable hands-on veterinary experiences by addressing the needs of animals on campus as well as animals in the San Luis Obispo.

This study thoroughly investigated the student who have taken or are currently taking any of the five courses taught at the CPVC. The research was accomplished through a survey questionnaire. The student questionnaire was conducted by the researcher at Cal Poly-SLO and was administered during the spring quarter of 2014. The analysis identified that hands-on learning experiences were most valued by students at the CPVC. A mission statement for the CPVC was also development for a better understanding of the clinic as a whole for the Cal Poly students, faculty, and San Luis Obispo community.

The survey results have determined the preferences of the students with regards to interest in certain clinical experiences which included anesthetic surgery along with students preferred interest in animal species- small animals. The survey results also provided the CPVC with data regarding the importance of difference benefits of the CPVC offered to student and the student satisfaction level of different factors of the CPVC. This information will help the Animal 
Science Department at Cal Poly by enhancing the needs of the students in the program and preparing future veterinary medical students with necessary skill sets. 


\section{TABLE OF CONTENTS}

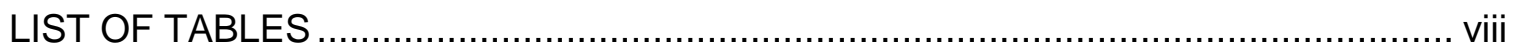

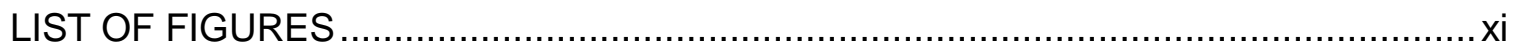

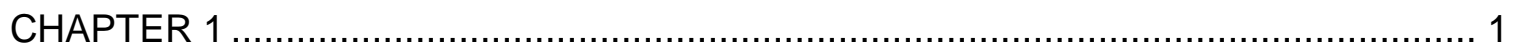

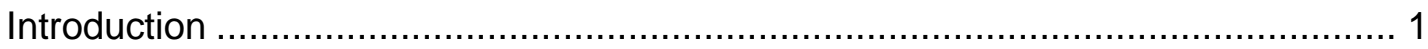

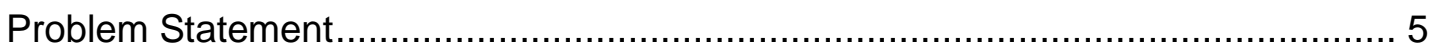

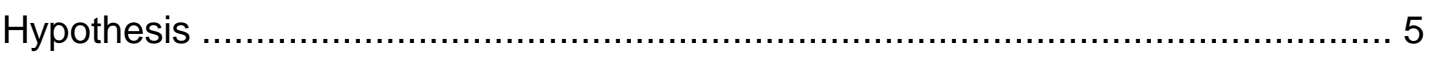

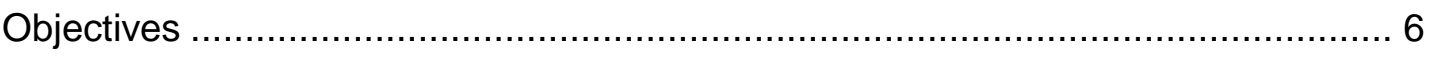

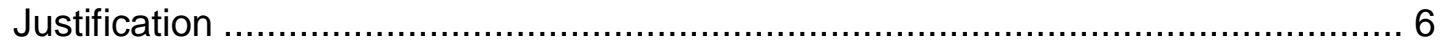

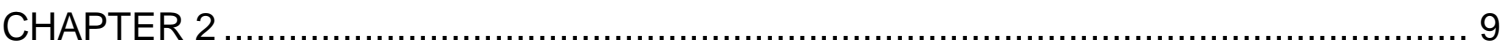

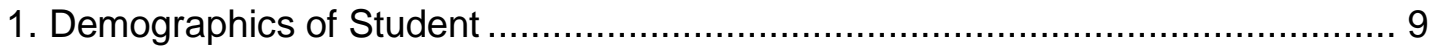

1.1. Demographics of College of Agricultural Students ……............................. 9

1.2. Demographics Animal Science Department Students ................................10

1.3. Demographics of Pre-Veterinary Students ...............................................11

2. Colleges with an On-Campus Veterinary Clinic .............................................13

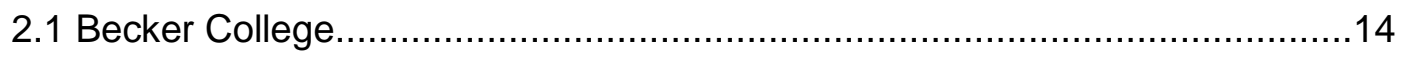

2.2 California State Polytechnic University- Pomona.......................................15

3. Applied Skills Needed by Students ............................................................

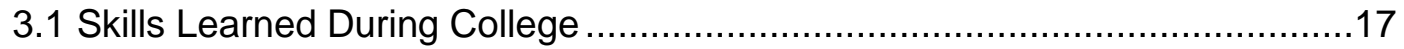

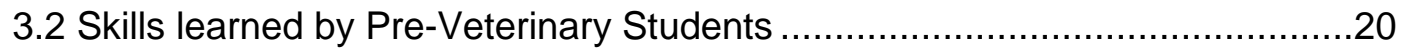

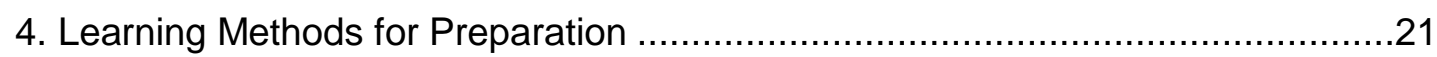

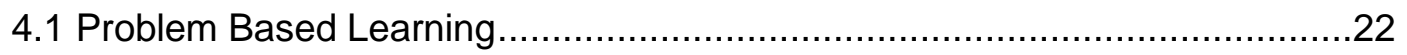

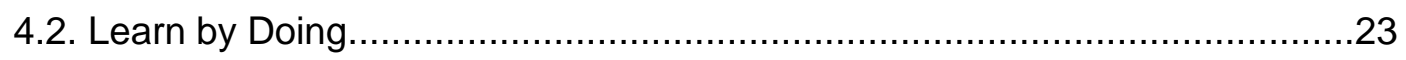

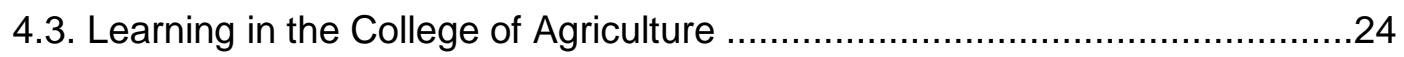

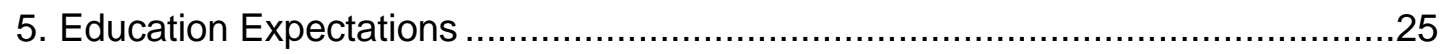

5.1 The Relationship between Quality and Expectations.................................26

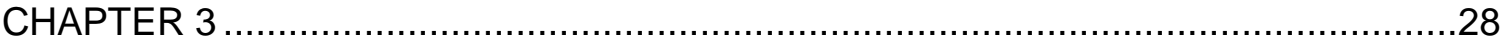

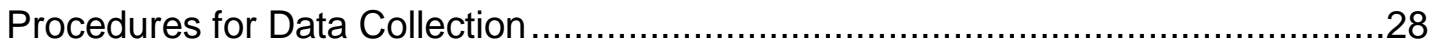

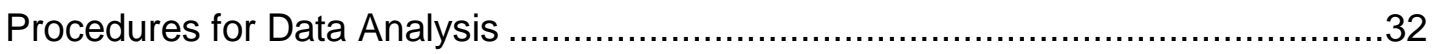

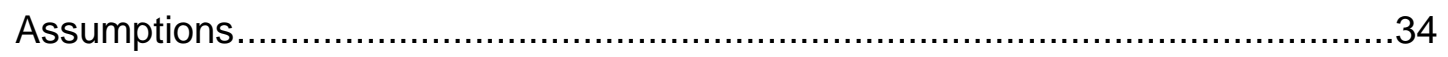

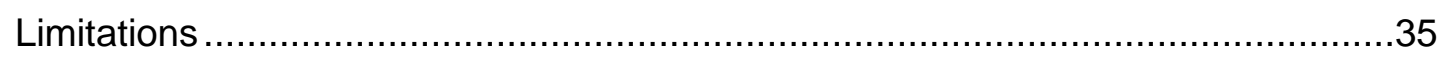

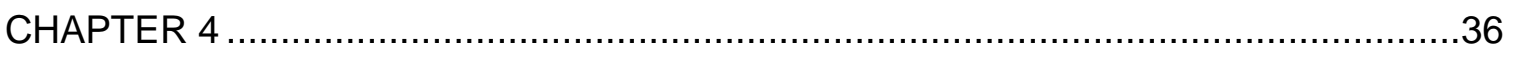

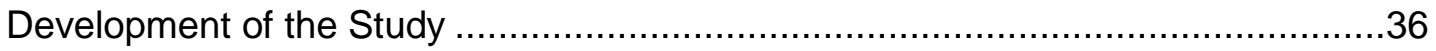




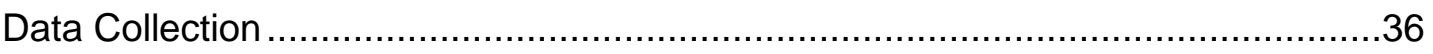

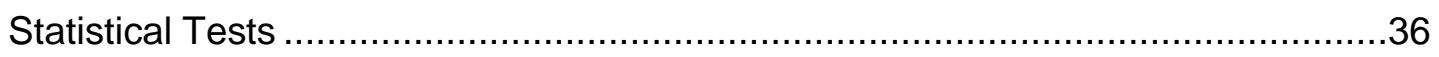

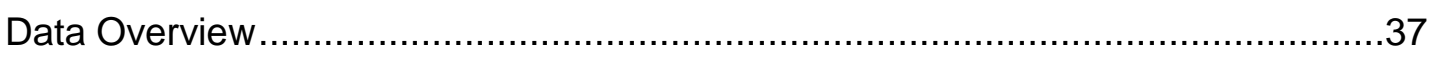

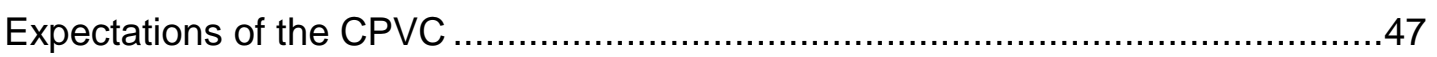

Pre-Veterinary Undergraduate Students and Academic Class Standings ...............50

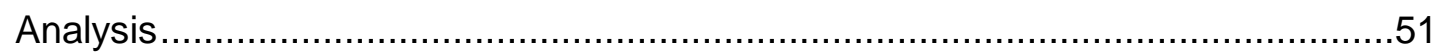

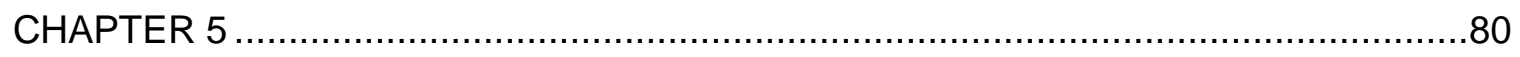

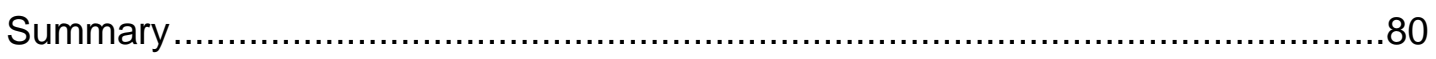

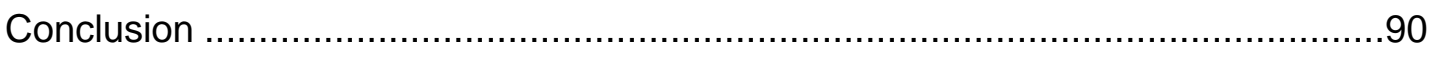

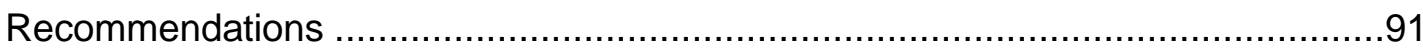

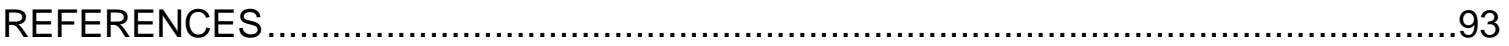

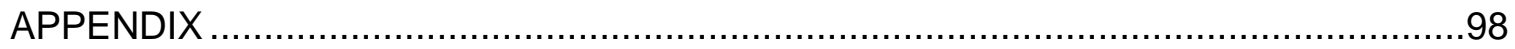




\section{LIST OF TABLES}

Table 1. Gender breakdown of pre-vet undergraduate respondents

Table 2. Respondents' academic standing breakdown ................................... 38

Table 3. Respondent current residence breakdown ...................................... 38

Table 4. Respondent program plans for after graduation breakdown................ 40

Table 5. Respondent likelihood to recommend the CPVC.............................. 42

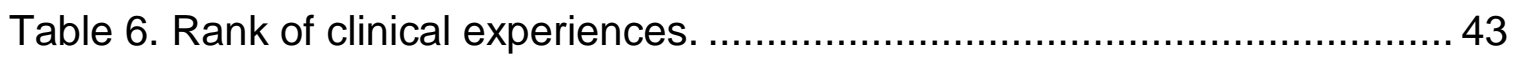

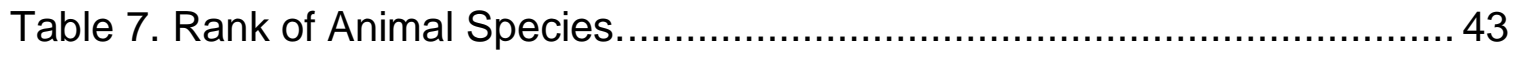

Table 8. Respondents breakdown of rating of extremely important benefits ...... 46

Table 9. Respondents breakdown of rating of very important benefits.............. 46

Table 10. Respondents breakdown of rating of extremely satisfied factors........ 47

Table 11. Respondents breakdown of very satisfied of factors. ....................... 47

Table 12. Gender breakdown of Pre-vet undergraduate students....................51

Table 13. Academic standing breakdown of Pre-vet undergraduate

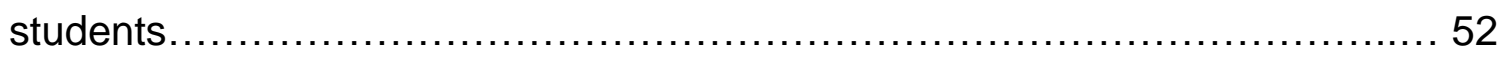

Table 14. Current residence breakdown of Pre-vet undergraduate students

Table 15. College major breakdown of Pre-vet undergraduate students............ 53

Table 16. Involvement of Pre-vet undergraduate students.............................. 54

Table 17. Hours spent at the CPVC by Pre-vet undergraduate students. .......... 56

Table 18. Number of quarters spent at the CPVC by Pre-vet undergraduate

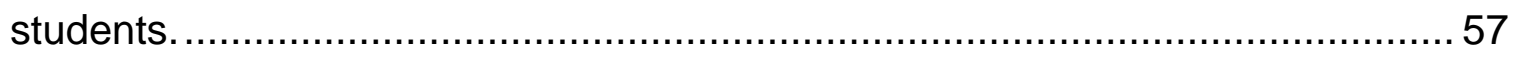

Table 19. Programs Pre- Veterinary undergraduate students plan on attending

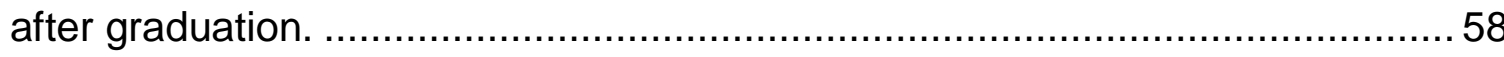


Table 20. Gender breakdown of upperclassmen students.

Table 21. Pre-vet undergraduate student breakdown of upperclassmen students.

Table 22. Current resident breakdown of upperclassmen students..................60

Table 23. College major breakdown of upperclassmen students. .................... 61

Table 24. Involvement of upperclassmen students....................................... 62

Table 25. Hours spent at the CPVC by upperclassmen students..................... 64

Table 26. Number of quarters spent at the CPVC by upperclassmen students...

Table 27. Programs upperclassmen students plan on attending after graduation.

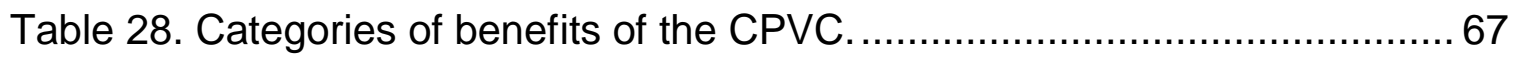

Table 29. Respondent breakdown of extremely important benefits of the CPVC.

Table 30. Veterinary Skill Development rating scale of importance breakdown of

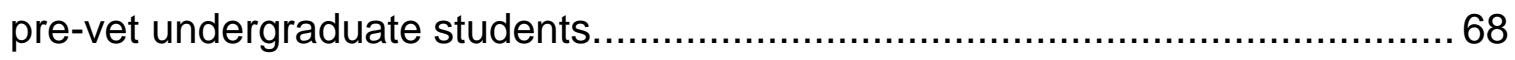

Table 31. Veterinary Career Preparation rating scale of importance breakdown of

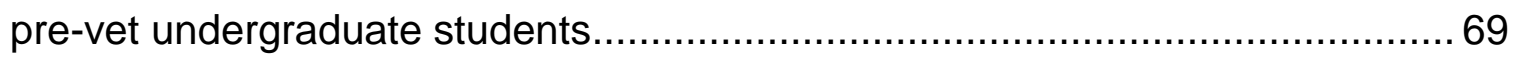

Table 32. Facility Staff rating scale of importance breakdown of pre-vet

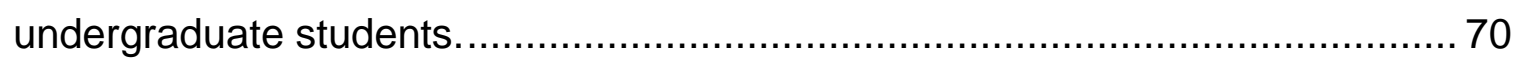
Table 33. Veterinary Skill Development rating scale of importance breakdown of academic class standings for Cal Poly students.......................................... 70 
Table 34. Veterinary Career Preparation rating scale of importance breakdown of academic class standings for Cal Poly students......................................... 71

Table 35. Facility Staff rating scale of importance breakdown of academic class standings for Cal Poly students. 72

Table 36. Chi-squared test statistic value for important benefits of the CPVC.....

Table 37. Respondent breakdown of extremely satisfied factors of the CPVC....

Table 38. Veterinary Skill Development rating scale of satisfaction level breakdown of pre-vet undergraduate students.

Table 39. Veterinary Career Preparation rating scale of satisfaction level breakdown of pre-vet undergraduate students.

Table 40. Facility Staff rating scale of satisfaction level breakdown of pre-vet undergraduate students.

Table 41. Veterinary Skill Development rating scale of satisfaction level breakdown of academic class standings for Cal Poly students. 76

Table 42. Veterinary Career Preparation rating scale of satisfaction level breakdown of academic class standings for Cal Poly students. 77 Table 43. Facility Staff rating scale of satisfaction level breakdown of academic class standings for Cal Poly students.

Table 44. Chi-squared test statistic value for satisfaction levels of factors at the CPVC 


\section{LIST OF FIGURES}

Figure 1. Animal Science courses taken by respondents.............................. 41

Figure 2. CPVC Strengths according to the respondents................................44

Figure 3. Future changes for CPVC according to the respondents .................. 45

Figure 4. Pre-vet undergraduate students' involvement at the CPVC. ..............55

Figure 5. Upperclassmen breakdown of student involvement at the CPVC. ......63 


\section{CHAPTER 1}

Introduction

In America, a growing number of young people are recognizing the value of a college education, aspiring to take challenging courses and internships, and setting their sights on a successful employment or professional school after graduation. As reported in the World Bank (2002), the role of higher education is even more influential than ever. In the past ten years, undergraduate enrollment has increased 38 percent (NCES, 2014).

When preparing students with the skills and attributes demanded by the workforce, the effectiveness of the education system is called into questioning. A study conducted by Cal Poly faculty examined the essential skills required for the success of an agribusiness graduate (Noel \& Qenani, 2013). The results were consistent with previous literature, concluding that employers prefer graduates that possess advanced critical thinking skills, be a good team worker, able to communicate well, and are creative thinkers.

The core mission of the agricultural higher education programs in general is to prepare students for future careers in the agriculture industry. In the past, agriculture departments at universities have not been able to meet the demand of future employers' desired attributes of undergraduate students. Researchers, Love and Yoder (1989) reported in the early 1980s agriculture 'representatives addressed the undergraduate's lack of practical experience, inability to solve

problems and communicate effectively.' Many agriculture colleges have faced 
many changes including a student focus change to a larger emphasis on companion animals, and veterinary medicine.

Since the 1980s many universities have encouraged undergraduate student involvement by participating in department clubs, student organizations, and on campus activities. In particular, animal science departments, a subdivision of most agriculture colleges have developed career pathway programs to assist students in acquiring skills for employability in special career areas (Slusher et al., 2010).

Many colleges and universities offer courses that help students develop career required skills with hands-on leaning components associated with the courses (Sung et al., 2013). California Polytechnic State University in San Luis Obispo, has taken the concept of preparing students with the proper skills demanded by future employers and professional schools one step further through the school motto, 'Learn by Doing.' Cal Poly has had success with their motto in attracting prospective student and encouraging new students to discover and implement change within their field of study. 'Learn by Doing' is more than a motto at Cal Poly, it is the foundation of education in all the colleges at the university, but specifically resembles the mission behind the College of Agriculture, Food and Environmental Science. For example, students working towards a degree in this college have the opportunity to collaborate closely with faculty and professionals by conducting meaningful research in laboratories and field environments. Students are offered over twenty hands-on or enterprise courses while working towards their undergraduate degree at Cal Poly. Through 
hands-on practical experiences, students are able to replicate the actions and environment they will find in the workforce after graduation.

Within the Animal Science Department at Cal Poly, faculty not only has to prepare undergraduate students for future careers in agricultural, but also have the task of assisting students with preparation for veterinary medical school as a possible future career goal. As a pre-veterinary student at Cal Poly, students have the opportunity to participate in numerous activities at the Cal Poly Veterinary Clinic (CPVC) on the campus. The CPVC is a student run veterinary clinic, overseen by one veterinary faculty member and three student lab managers. The clinic's main purpose is to expose students to hands-on veterinary experiences that one would normally not experience within the limitations of a classroom lecture. The veterinary clinic was designed to promote teaching while addressing the needs of the animals on campus and pets from the San Luis Obispo community. Animal science undergraduate students have a variety of opportunities to become involved at the clinic including courses in technical veterinary skills, companion animal science, anatomy and physiology of farm animals, systemic animal physiology, enterprise, and as student managers at the veterinary clinic. In the past, students volunteering at the veterinary clinic take part in community activities including spay and neuter days and vaccination clinics.

The CPVC's primary teaching focus centers around a problem based learning teaching method. Students are regularly presented with a problem or case and as a class, with the guidance from the veterinarian, use problem 
solving skills to determine a solution. Student learning is directed by solving problems through the experiences. By participating at the CPVC, students are exposed to a critical part of career exploration and skill building. All the courses taught at the CPVC have a hands-on component associated with a lecture. Therefore, students are shown what a real career in the veterinary medicine will be like. The CPVC's model addresses the fact that not all learning can be done through textbooks offering students the opportunity to experience the trial and errors behind veterinary medicine and develop effective problem-solving skills. Overall, undergraduates participating at the CPVC learn how to think independently, as well as collaborate with different groups as a team to solve complex veterinarian medical cases.

Along with learning the practical skills of veterinary medicine, students at the CPVC also develop highly desirable communication skills. The majority of the veterinary profession recognizes the importance of good communication skills (Radford et al., 2003). In past decades, undergraduate students receive minimal instruction in communicating specifically with the interaction between veterinary professionals and their clients. Cal Poly is striving to bridge the gap between preveterinary undergraduate students and career preparedness; therefore, students are exposed to real clients from the Cal Poly community and are able to practice their communication skills with them. As student managers at the CPVC, undergraduates improve their customer service communication skills by working closely with medical vendors, suppliers, and clients as well. These practical 
experiences of developing communication skills can be carried over into all aspects of veterinary medicine.

In an effort to maximize student's experience research was conducted to determine the important benefits of CPVC and establish areas of interest for students participating at the clinic. This study will explore students' levels of satisfaction of different aspects of the CPVC and assess possible improvements for the clinic to better meet the expectations of the students. Furthermore, there has been a lack of research at the undergraduate level of the importance of hands-on experiences in agricultural departments. School faculties are responsible for the continual restructuring and refocusing of the pre-veterinary animal science program in order to supply students with the relevant skills required by future employees and veterinary medical school. And the results from this study should be of interest and offer insight to both the animal science program at Cal Poly, as well as faculty in other hands-on learning departments.

\section{Problem Statement}

Does the Cal Poly Veterinary Clinic provide Cal Poly students important benefits in preparation for a future career in agriculture or veterinary medicine?

Hypothesis

Through a thorough analysis of the Cal Poly Veterinary Clinic, a hands-on learning experience at the CPVC is one of the important benefits in preparing for a career in agricultural or veterinary medicine 


\section{Objectives}

1. To administer a survey to Cal Poly students to gather information about the CPVC

2. To prioritize the importance of certain benefits offered to students that participate at the CPVC

3. To identify students' areas of interest in the field of veterinary medicine

4. To identify students' species of interest in the field of veterinary medicine

5. To prioritize areas of improvement to better satisfy the students participating at the CPVC.

6. To develop a mission statement that reflects the needs and expectations of the students participating at the CPVC

Justification

According to the National Center for Education Statistics, enrollment in degree-granting colleges has increased by 11 percent between 1990 and 2000 . In the past ten years, undergraduate college enrollment has increased by 37 percent. Student enrollment went from 15.3 million to 21 million from 2000 to 2010. During those ten years, full-time enrolled students rose 45 percent, while part time students rose 26 percent. In the next five years, these students currently enrolled in college programs will have graduated and be seeking employment. Higher education needs to implement programs in their curriculum to prepare students with job-ready skills before graduation. As the rate of college enrollment increases, the value of a college education will decrease. Therefore, 
employers expect their future employees to be college educated as well as have field experience.

It is important for Cal Poly to offer students the appropriate tools and opportunities to prepare them for successful employment in a career in agriculture or continuation of education at a post-secondary professional school. The Cal Poly Veterinary Clinic is one, of many, ways to prepare students with desired skills by future employers by offering students hands-on practical experience in their field of study. Through the diverse exposure of on campus animals, pre-veterinary undergraduate students can build their skill set to be a successful employee in the field of veterinary medicine. The Cal Poly Veterinary Clinic is one way pre-veterinary undergraduate students can prepare for a future career in veterinary medicine.

With only 27 veterinary medical schools in the United States and class sizes less than 100 students, getting into veterinary school is a challenge. Each year over 15,000 hopeful applicants apply to fill approximately 2,500 seats. Students have to be realistic about getting into veterinary school; preparing for veterinary school should be an undergraduate's main concern. In recent years, applicant's high GPA is not enough to be a successful candidate for veterinary medical school. According to Association of American Veterinary Medical Colleges an application requires a minimum of 180 practical hours prior to submission, but continues to state that admitted applicants have on average of 2,000 hours of veterinary experience (AVMCAS, 2013). 
Veterinary medical schools want students that are "well-rounded" including practical experience, high GPAs and strong test scores. The selection committee considers animal experience to be an important part in the preparation for the curriculum. A basic knowledge of the veterinary medical profession is best gained through closely observing the role of various member of the health care team in traditional practice settings. Students are able to benefit from these experiences and discover what it is like to be veterinarian. Students learn about what a professional does daily, including how to effectively plan a work day, allow time for the unexpected, stay current in the profession, address uncertainties and strike a balance between personal and professional life all while deriving satisfaction from the daily routine. Exposure to animal experiences is a crucial part of one's veterinary medical school application.

The Cal Poly Veterinary Clinic on campus is one way pre-veterinary undergraduate students in the animal science department are able to prepare themselves for a future in veterinary medicine. By serving the animals on campus and the Cal Poly community, students are exposed to a diverse range of animals expanding from companion animals to livestock to reptiles. With the prospect of a new veterinary teaching hospital being built in the near future, it is important for the CPVC to remain a vital part of the Animal Science Department and exceed in preparing undergraduate students for a career in agriculture, specifically one in the veterinary medicine field. 


\section{CHAPTER 2}

\section{Demographics of Student}

In the Freshman Survey administrated by Higher Education Research Institute to incoming college freshmen, gender demographics were explored (HERI, 2000). The first five years of the survey (1966-1971) indicated most entering college students were male, 55 percent. Since 1971 there has been a steady increase in female freshman entering college. As of 2011,55 percent of entering college students are female (HERI, 2012). This trend of female majority can be seen throughout a variety of majors and is becoming a trend, as well, in graduate and professional schools. Furthermore, the college of agriculture of many universities in the United States has also experienced the switch in gender majority over the past few decades.

\subsection{Demographics of College of Agricultural Students}

When the United States first developed agriculture colleges at universities in 1910, approximately 33 percent of the US population was involved with agriculture, but today only 1 percent of the US population is involved in agriculture (U.S. Bureau of the Census 1975). Over the past one hundred years, demographics of agricultural college students have changed. In regards to gender demographics, the majority of agricultural college students were male, now literature identifies that almost 80 percent of agricultural students are female (Gaspard et al., 2011). 
In a study conducted at Louisiana State University in 2011, the demographics of a freshman introductory to agriculture class were examined. Almost 85 percent of the students indicated white/non-Hispanic on the survey and 79 percent identified as females. The study supports the change in gender demographics of animal science students at universities with the trend shifting towards more female students pursuing a degree in animal science. However, the literature does not show how the change in demographics affects the agriculture industry and change in skills needed by the changing demographics.

\subsection{Demographics Animal Science Department Students}

Over the past one hundred years, animal science departments have faced many changes. Originally, land grant universities established animal science departments to educate students on food producing animals with the occasional study on horses as work animals (Britt et al., 2008). There continues to be an increase in student enrollment in animal science programs, but with a change of focus to studies on companion animals, exotic animals and veterinary medicine. Furthermore, these new age animal science students are typically female. With the changing views on animals in society from animals use mostly in agricultural food production to companion animals, a change in the animal science department has been inevitable. It can be predicted that the future of animal science departments will include a wider range of majors offered with a greater emphasis on sustainability, environmental effects, and social awareness instead of production efficiency. Addition financial limitations will force departments to build strong relationships with the surrounding community on a 
local and national level in order to achieve high academic standards, research funding, and develop successful student outreach programs (Britt et al., 2008). Even with an overall decrease in college students interested in agricultural, the animal science department will continue to thrive and the department's involvement with society will be crucial over the next century.

Another change in the animal science department has been the animal science courses taught to undergraduate students. With a shift in demographics and the use of animals in general, there has been a greater focus on preveterinary companion animal studies. In a 2008 survey, 78 animal science departments were asked questions regarding companion animal teaching (Alrich \& Irlbeck, 2008). Of the departments asked, 74 percent were teaching courses related to companion animals and 23 percent had companion animal programs. This survey also concluded that the student population was 68 percent female, 65 percent urban and 64 percent wanted to have a career in veterinary medicine with 70 percent focusing on companion animals. These changes in teaching are directly correlated to the change in demographics the animal science department has endured. In a study that looked at the demographic of students in an introductory animal science course at Ohio State University concluded that almost 80 percent of the students are female which is similar to previous literature findings (Peffer, 2010, \& Gaspard et al., 2011).

\subsection{Demographics of Pre-Veterinary Students}

There is a lack of previous literature on the research topic of undergraduate pre-veterinary students in universities across the United States. 
This is predominately because educational universities generally do not have a specific major directly correlating with the preparation for veterinary medical school; instead they have future career path guidelines associated with the requirements of admissions to veterinary medical school and some science based agriculture majors. More specifically, pre-veterinary students are animal science or equivalent majors in the college of agriculture. However, when looking at career objectives of an introductory animal science course 59 percent of students indicated a career in veterinary medicine which then increased to 68 percent of total students when only considering the students who declared an animal science major (Gaspard et al., 2011).

Demographic trends of pre-veterinary undergraduate students are similar to previous literature of agriculture college and animal science major students with a majority of the students being females (Elmore, 2003, \& Gaspard et al., 2011). Female enrollment in animal science courses reflects the drastic change in the ratio of men to women enrolled in veterinary medical school over the past three decades with women representing more than 70 percent of veterinary students (Elmore, 2003).Furthermore, the change in demographics is evident in the class statistics of the UC Davis School of Veterinary Medicine graduating class of 2016, of the 138 students 105 are females (UC Davis Veterinary Medicine, 2014). Of the pool 1,142 applications received by UC Davis Veterinary Medical School, only 217 were males.

Another change in pre-veterinary undergraduate students who plan on attending a veterinary medical school is the students' lack of agriculture 
background before entering undergraduate college. A recent study of twenty-six United States veterinary medical colleges concluded that a large majority (62 percent) of students were raised in urban upbringing with little to no agriculture background previous to college (Jelinski et al., 2008). With the majority of present and future students at veterinary medical schools lacking a strong and diverse agricultural background it is imperative for undergraduate universities to supply students with the proper skill sets needed to be successful in a veterinary medicine career. Research needs to continue to investigate the required skills demand by both an admission committee for veterinary medical school and veterinary professionals.

\section{Colleges with an On-Campus Veterinary Clinic}

In general, veterinary clinics or teaching hospitals located on university campus are associated with veterinary medical schools. For instance, University of California, Davis School of Veterinary Medicine has the William R. Pritchard Veterinary Medical Teaching Hospital on the grounds of the veterinary medical school, located adjacent to UC Davis main campus. Because of the benefit of proximity, undergraduates at universities that also have a school of veterinary medicine have the opportunity to participate at the university's teaching hospitals (UC Davis VMTH, 2014). At UC Davis, undergraduates students that are a part of the pre-veterinary club can apply for quarter long internships at a variety of divisions of the large and small teaching hospital (Vet Aide Club, 2014). The main goal of the teaching hospital at UC Davis is to provide training opportunities and clinical experiences for veterinary medical students and post graduate 
veterinarian residents, along with providing opportunities for undergraduate students to interact with staff and veterinary medical students at the teaching hospital. Of the thirty veterinary medical schools in the United States, twenty nine of the schools are associated with a veterinary clinic or teaching hospital (AAVMC, 2014).

\subsection{Becker College}

There is only a limited number of four year college campuses that offer a student-run veterinary clinic to their undergraduate students. One example is Becker College located in Leicester, Massachusetts. Becker College is a unique, small college that has long been recognized for its intimate learning environment and innovated educational programs (Becker College, 2014). The university continues to gain national recognition in programs such as Animal Science and Nursing for its excellent hands-on learning teaching methods. Specifically, Becker College is number one in New England and ranked fifteenth nationally among four- year private institutions in awarding undergraduate animal science degrees in 2011-2012. Becker College prides itself as one of the few programs nationwide that operates a student working animal clinic on campus (Becker College, 2014).

The Becker College Veterinary Clinic serves as a teaching clinic for undergraduate students interested in veterinary medicine in the animal studies program. The Becker College Veterinary Clinic offers its students opportunities to conduct examinations and perform procedures under the supervision of faculty veterinarians. This clinic, located at the Lenfest Animal Health Center on the 
Leicester, Massachusetts campus, is a full functioning veterinary clinic, but also a grooming salon and teaching animal kennel. The veterinary clinic is open to the public during the school year from August through May of each year with hours of operations Monday through Friday 8:30 am to $5 \mathrm{pm}$. The clinic caters to the local community and provides well visits and non-emergency care for dogs, cats, other small mammals, and birds. The Becker College Veterinary Clinic also offers minor surgeries and routine dental care. The clinic is headed by three staff veterinarians, a director of animal science programs, director of clinical services, and a full time groomer. All clinic services, scheduled only when classes are in sessions, are at a moderately discounted fee and all teaching animals are available for adoption by the public at the end of each semester (Becker College, 2014).

\subsection{California State Polytechnic University- Pomona}

Besides from Becker College, most undergraduate universities do not have an on-campus clinic or programs associated with careers in veterinary medicine. However, Cal Poly Pomona (Pomona) has the only four-year veterinary technician program in California. Students in this nationally accredited program earn a Bachelor of Science degree in Animal Health Science and are eligible upon graduation to take state and national veterinary technician board exams (Pomona, 2014). Similar to Cal Poly, Pomona emphasizes hands-on learning as a major component of their veterinary technician program. In this program, students are required to work in four different clinical settings including large animal, small animal and specialty clinic. All the animal clinics are 
associated with Pomona making their veterinary technician program unique to all other veterinary technician programs.

This mission statement for Pomona animal science department states, "the Department of Animal Science endeavors to train its majors to understand and critically evaluate production and companion animal nutrition, health status and physiology. The depth and breadth of these programs should adequately prepare them for graduate/professional school or a career in industry" (Pomona, 2014). The department's primary goal is to provide students with the scientific knowledge and training that would allow the students to enter into veterinary medical school, graduate school, or a scientific career in animal science. On the Pomona animal science department webpage, two "Student Learning Outcomes" are outlined. The first is "students will have the knowledge of domesticated production and companion animal nutrition, health status, and physiology" (Pomona, 2014). This means that at the time of graduation students should have knowledge and skills of large and small animal husbandry skills, large and small animal nutrition knowledge, and basic animal research techniques and methodology. The department's second student learning outcome is "students will learn to evaluate and understand the factors that influence the impact of animal health, animal welfare and animal care on; other animals, people, society, and the environment" (Pomona, 2014). By the time of graduation students will have knowledge in production animals and the environment, zoonotic diseases and their relationship to people and society, and the human animal bond. 


\section{Applied Skills Needed by Students}

The generation of students currently enrolled and graduating from college is known as the millennial generation, also referred to Generation Y. Millennials were born during the early 1980s through the mid-2000s (Sheahan, 2005). Researchers, Howe and Strauss explain that millennials are confident, teamoriented, and feel pressure to excel in whatever they choose to do (2000). Because Millennials have the mind frame to succeed in a hands-on learning environment at universities, undergraduate students today have a great advantage of learning skills desired by future workforce.

\subsection{Skills Learned During College}

With the ever changing demands of the workforce, research has explored the challenges higher education universities have in preparing undergraduate students with skills desired by industries. Steps are being taken to define and identify key skills needed for employment especially at the higher education level for students. Most importantly, colleges have since emphasized core curriculum to better meet the demands of the agriculture industry and produce students excelling in the required skills.

Both undergraduate students and future employers' rank critical thinking skills as a high importance, as well as, being able to analyze situations, make decisions and solve problems on their own (Noel \& Qenani, 2013). One study outlines the importance of critical thinking skills, but it does not address how future students in either the agribusiness department or another agricultural 
program will develop these required skills (Noel \& Qenani, 2013). Problemsolving and critical thinking skills are the most cited educational need in college curriculum (Rhykerd et al, 2006). In order to become an effective critical thinker, students must be taught the proper techniques to analyze, decide and solve problems. In a time when many agricultural students do not have agriculture background knowledge, it is important to supply students with opportunities to gain hands-on experience to practice their critical thinking skills in a supported environment. Also, student comprehension is increased through hands-on critical thinking exercises and application of real-world work situations. Through the use of simulations to provide experimental learning activities in agriculture, students become more proficient in understanding and applying decision making processes in the agricultural industry (Stewart et al, 2000).

Professionals in all agriculture fields, especially veterinary medicine recognize the importance of good communication skills (Radford, A.D. et al., 2003). Researchers, Telg and Irani (2005), found that agricultural communication programs during college education help students strengthen their communication skills for the workplace through the use of real world projects, research experiments, strong writing assignments, and exposure to diverse perspectives. This is one reason undergraduate programs are striving to prepare students with good communication skills. Furthermore, the use of simulations improves students' communication skills, and their ability to recognize and analyze situations efficiently. 
To develop these sought after skills; undergraduate medical students in the UK take courses with a large emphasis on role-playing. Through the interaction between students and professionals, students are able to develop their own communication skills in ways that are directly transferable to real-world clinical practice. The interactive communication skills courses encourage students to analyze their own communication with professionals, and consider their individual thought process used when deciding on solutions for diverse problems (Ellaway et al., 2003).

Changes in the modern workforce are transitioning the skills, knowledge, and attributes needed for a successful employee. Still employers rank critical thinking skills as a high importance, wanting future employees to be able to analyze situations, make decisions and solve problems on their own (Noel \& Qenani, 2013). Creativity was also ranked as a high importance. While no formal definition of creativity has been developed, it is agreed that creativity is thinking that aims to produce novel ideas or products that can add value to society. Clearly it takes more than knowing information from a textbook to be an ideal candidate in the workforce in today's society. While this study explains the importance of critical thinking skills, it does not address how future graduates in either the agribusiness department or another agricultural programs, will develop these required skills.

With the challenges universities continue to overcome, higher education must continue assessing and modifying their curriculum to meet the needs of the students and prepare them for the workforce. Following the review of literature 
on applied skills from college graduate students, one question still have not been answered: is the Cal Poly Veterinary Clinic implementing these required skills demanded by the industry in the school-based teaching curriculum?

\subsection{Skills learned by Pre-Veterinary Students}

With the changing demographics of students in animal science majors, specifically students with a pre-veterinary concentration, there needs to be a balance between the industry needs and the universities core curriculum. Major changes in the animal science department typically come from inputs outside the department faculty including industry professionals in different fields of agriculture. Both the industry and education needs must be considered with developing curriculum in a given field and skills considered necessary for future employment and careers. Undergraduate students studying in the animal science field with a concentration in pre-veterinary science learn skills through college education as preparation for a career in veterinary medicine. For instance, in introductory classes at Ohio State University, animal science students gain knowledge and critical thinking skills to adequately address concerns in maintenance, reproduction and performance of domesticated animals (Peffer, 2010). Students learn knowledge and technical skills through interactions with animal production and management. The skills learned through interactions will be beneficial in future veterinary medicine careers.

As acceptance into veterinary medical school becomes more difficult, undergraduate universities need to adapt to the challenges to adequately prepare students for post- secondary education. In recent years, Oklahoma State 
University has revised their pre-veterinary science option to extend into a fourth year of education (Buchanan, 1994). Previously, students were accepted into veterinary medical school after their third year of education, but recently this is not always the case. To enhance the students' chance of acceptance into veterinary medical school, Oklahoma State University modified its program to expand students' knowledge and skill sets by offering additional courses in science and animal production. Oklahoma State University is one of many schools working hard to revise the curriculum to stay ahead of the ever changing demand for desired skills and knowledge in both the future workplace and education programs. Unfortunately, little research has been done on what skills pre-veterinary undergraduate students retain by going through these programs.

\section{Learning Methods for Preparation}

Workers in the $21^{\text {st }}$ century need skills like problem-solving, critical thinking, decision making, time management, and communication to be successfully employed in the workforce. One researcher purposes that there is a 'general consensus that occupational preparation should begin something in high school' (Lynch, 2000). Several studies have examined career and technical education claiming that forty-one percent of the participants intended to pursue professional careers after high school. Lynch advocates the importance of integrating career and technical education into the overall education system (2000). Additionally, many skills required by industries like agriculture cannot be taught in a lecture-base course academic educational system. In today's world, learning cannot be confined to inside a classroom only. 


\subsection{Problem Based Learning}

Learning cannot be limited to focus on either academic achievement or personal development, but instead a combination of student centered learning of content knowledge and skill development. Doctors, both human and animal, of tomorrow must be able to learn, and be able to know how to learn. Students studying for future careers as a medical professional must have highly developed problem solving skills. One method to develop critical thinking and problem solving skills in university environments is through problem base learning. Previous literature has stressed the importance of problem based learning methods. Problem based learning (PBL) is student centered learning where classmates learn about a subject through the experience of solving problems.

Problem based learning was first developed by medical educators in the 1950s because of the increase in medical knowledge required to be known by doctors. PBL improved traditional classroom problem-solving skill development to reflect clinical practices (Barrows \& Tamblyn, 1980). BPL forces medical students to work in teams and learn by solving realistic medical problems. BPL continues to be a favorite learning method in many human medical schools and is becoming more prevalent in veterinary medical schools. In one study of undergraduate students, Hake concluded that head-on, hands-on activities are strongly superior to lecture-centered instruction (1998). BPL has been extensively researched in medical students, but very little research has been conducted on undergraduate students. 


\subsection{Learn by Doing}

There has been a lot of academic research on different teaching methods including the idea of 'learn by doing.' Traditional chalk and lecture teaching methods are becoming less popular in university settings, and now focusing on teaching methods that centers around student engagement. In a study conducted on the teaching methods of undergraduate economic courses, the research suggests a teaching method of learning by doing (Ghosh, 2013). This teaching method is similar to problem based learning where students learn through realistic work experiences. As described by the researcher, students learn significantly more real life applications and thus apply their knowledge to real life situations. The research proves that students are more likely to retain knowledge from the whole course when exposed to learn by doing teaching methods.

In preparing students for the $21^{\text {st }}$ century workforce, undergraduate educational curriculum's main objective is to equip students with the skills and knowledge required to be successful in the workforce. A study conducted on undergraduate engineer students concludes that the use of self-directed, projectbased learning methods prepares students with the skills to think critically and collaborate in teams (Savage et al., 2007). In learn by doing settings, students learn to work in teams in practical situations while solving technical problems as well as making a contribution to society. Furthermore, little research on the implementation of 'learn by doing' teaching methods have been examined in the field of agriculture. 


\subsection{Learning in the College of Agriculture}

As previously discussed animal science departments have undergone drastic changes over the last fifty years. With a larger emphasis on companion animals and animal welfare, animal science departments now face the challenge of effectively educating undergraduate students to become successful employees in companion animal careers. Previous literature has developed many alternatives for learning methods in the animal science department to encourage successful student learning (Mills, 2003 \& Bowden, 2003). Programs like freshman interest groups, hands-on laboratory learning, and student run clinics have all contributed to benefit the students' success as an undergraduate college student.

A recent study at Kansas State University examined what motivates an agriculture student to learn (Mankin, 2004). In a questionnaire administered to the College of Agriculture on a variety of in-class and out-of-class factors concluded that students of all grade levels and GPAs prefer interactive classroom environments. Students specifically prefer small class sizes, hands-on learning environments, and class wide discussions. Students also wanted assignments that provide real-life experiences and for professors to help students build the ties between their assignments and the industry. Hands-on learning activities are one way professors are able to close the gap between teaching and learning. While this study stresses the importance of hands-on, problem solving learning, it does not address how to implement these teaching 
strategies into the agriculture departments to better prepare students for future careers.

In a study performed at the University of Missouri- Columbia preveterinary freshmen interest groups were tested to see if they are more likely to achieve academic success (Purdie et al. 2007). The research was unable to significantly conclude if participating in freshmen interest groups increased academic success or acceptance into veterinary medical school. However, the research did suggest that learning community groups and freshman interest group programs are a useful tool for faculty to enhance the learning experience of students. This study is only limited to the enhancement of student education for learning inside a classroom, but previous literature has shown that learning cannot be limited to a classroom.

\section{Education Expectations}

As a key area for creating a successful educational university, greater attention to the quality of education is being explored. Quality in higher education is a complex concept and an appropriate single definition of quality is lacking. At the university level there are many parties including students, faculty, professionals, staff members, and government, which all have an opinion on quality of higher education. This paper will focus solely on the particular view of students. 


\subsection{The Relationship between Quality and Expectations}

Service quality in higher education, as defined by researchers, O'Neill and Palmer, is "the difference between what a student expects to receive and his/her perceptions of actual delivery" (2004). The idea of using students' expectations for understanding service quality in higher education is a complicated matter because of the varying views of quality expectations (Sandmaung \& Khang, 2013). There are three types of service expectations: desired service, adequate service, and predicted service (Zeithaml et al., 1993). Students have a desired level of service which they hope to receive. This desired service combines what students believe can be achieved and what should achieved. Students will also express a minimum level of acceptable service which is the adequate service type. In between the two types of expectations is an area of tolerance that students are willing to accept. The final type of expectation is where students have a predicted level of service they believe the school can provide for them.

Examining the nature of expectations in higher education is an important contribution to determining the quality of service being provided to the students. Many studies have been conducted on the students' overall expectation of higher education, specifically the university institute as a whole. Very little research has studied students of a particular major involved in a certain education preparation field like students participation at the CPVC. It has been concluded that opinions of students in research has been found to be very useful in several ways. The first being, students' assessments can be used to improve a faculty's teaching style and methods. The second is student assessments can give feedback about 
a course curriculum and facilities used by the students. Moreover, the various qualities of expectations of programs in higher education can be further developed into the programs philosophy, mission, objectives, and implementation plans. 


\section{CHAPTER 3}

Methodology

Procedures for Data Collection

This study focuses on the Cal Poly Veterinary Clinic on Cal Poly campus and determines the important benefits of the CPVC with regards to preparing students for a successful career in agriculture, specifically veterinary medicine. The research also explores students' levels of satisfaction and possible improvements for the future of CPVC. The results of this study are to assist the animal science department's pre-veterinary science program to enhance the needs of the students while meeting the needs for their future careers in veterinary medicine.

To determine the student preferences, level of satisfaction, and important factors of the CPVC primary data was collected through a survey. The results from this research were derived from the responses of the survey questionnaire. A survey questionnaire was used because of its ability to be administered to large quantities of individuals and its consistent responses can be easily quantified. The student questionnaire was conducted by the researcher at the California Polytechnic State University at San Luis Obispo and was administered during the spring quarter of 2014.

Since this research focuses on the importance of the campus facility, the survey was distributed to students who have participated in activities at the CPVC including animal science courses, laboratories, internships, volunteering, student teachers and management. The courses included the following: ASCI 
290- Veterinary Clinic Enterprise Course, ASCI 227- Companion Animal Science, ASCI 229 Anatomy and Physiology of Farm Animals, ASCI 310 Technical Veterinary Skill Course, and ASCI 438 Systemic Animal Physiology. To receive an effective response; surveys were distributed through Dr. Sprayberry's (head veterinarian and professor at the Cal Poly Veterinary Clinic) email to animal science classes. The respondents represent a variety of backgrounds ranging from freshmen to graduate students. The target population for this study was defined as all students at the undergraduate and graduate level at Cal Poly participating at the CPVC.

The survey was administered to over three hundred students in five different courses over four quarters including Fall 2012, Fall 2013, Winter 2014, and Spring 2014. A sample size of eighty students was obtained for the study. The criterion used for selecting individuals was based on the participants being an enrolled student in any of the five courses offered at CPVC. The survey was administered for sixteen days from April 21, 2014 to May 6, 2014. With about 30 percent of students taking more than one course a quarter, receiving a response rate of eighty surveys is an adequate sample size to achieve valid results.

The survey was designed using the Internet-based survey created Survey Monkey. This program was chosen because of its ability to easily distribute the survey to students and it is a cost efficient survey creator. An introduction stated at the beginning of the email was sent to students to explain the purpose of the study and provide a link to the survey. The introduction is included in Appendix 1. Consent information was also provided as the first question of the survey to 
ensure students that no personal information will be used and all answers were anonymous.

The survey totaled to be twenty three questions and can be found in Appendix 1. The various question subject matter included demographics of Cal Poly students, expectations, important benefits, satisfaction levels, areas of interest, and possible future changes of the CPVC.

This survey studied demographics of the population including gender, academic standing, major, current residency, and means to fund their college education. Questions $(2-5,8)$ will help describe the respondents and their background in agriculture. Questions 6 and 7 addressed the sample's agriculture and animal background. This question asked about family involvement in agriculture as farmers/ ranchers, agricultural educators, state representatives, or worked in veterinary medicine. Questions 9 and 10 will be used to determine the current and future career plans for student respondents. Respondents were asked what their future career plans after graduation including veterinary medical school, graduate programs, other doctoral programs, or registered veterinary technician program. Students were also asked if they are pre-veterinary students at Cal Poly. This survey also studied the demographics of which courses respondents are currently taking or haven taken in the past, number of quarters, and average hours spent at the veterinary clinic per week (questions 11-13).

The respondents were then asked questions 14 to 18 regarding the expectations, important benefits and satisfaction of the respondents with regards 
to the CPVC. In a short response question (14) respondents wrote about the CPVC meeting their expectations. Questions 15 and 16 asked respondents to rate a statement. Both questions 17 and 18 listed the same factors, but asked respondents to rank the factors on the importance (17) and level of satisfaction (18) of the CPVC. For questions 15 through 18 a Likert scale was used to assign a numerical value to each choice. This allows the researcher to analyze qualitative data into quantitative variables. The final average of the score represents the overall attitude to the question being asked. The ranking scale included extremely, very, slightly, somewhat and not at all. These questions became important when analyzing and determining students' perspective of the veterinary clinic. Therefore, it is of great interest to learn specifically which factors students deem as more important and which factors students are most satisfied with.

In questions 19 and 20, respondents were asked to rank in order of preference clinical experiences and species that could be found at the CPVC. These two questions are very important to the CPVC in determining which clinical experiences students are most likely to participate in, along with which species students involved at the CPVC would like to work with. The information for these questions will assist the CPVC with a better understanding of how to develop laboratory work for the courses offered at the CPVC.

Finally, the last three questions on the survey (21 -23), asked if respondents would recommend the CPVC, the strengths of the veterinary clinic, and possible future changes for the clinic. Question 21 uses a Likert Scale where 
respondents were asked how likely (extremely to not at all) they are to recommend the CPVC to other students. Questions 22 and 23 allows for multiple responses to ensure respondents are able to put forth a clear vision of the strengths and changes needed to be made at the clinic. This information is of great importance to the CPVC because the results will be used to determine which specific aspects of the clinic need to be changed.

\section{Procedures for Data Analysis}

After the completion of the survey, the results were exported from the online data base of Survey Monkey into Microsoft Excel for further statistical analysis. A statistical analysis of the data was conducted to determine the student preferences, level of satisfaction, and important factors of the Cal Poly Veterinary Clinic.

The data was made of nominal and ordinal data. Nominal data refers to a category and allows a number to be assigned for analysis. Nominal data can be counted but not ordered or measured. Questions 2 through 12, 14 and 22 through 23 resulted in nominal data. Questions 13 and 15 through 21 resulted in ordinal data. Ordinal data is when responses are ranked or put into some kind of rational order. Ordinal data can be counted and ordered but not accurately measured.

Each question was assessed by statistical tests. A chi-square test of independence was used to determine the relationship between two variables. This type of test was used when a deeper analysis of Question 17 and 18 was 
compare to the academic standing or pre-veterinary undergraduate student variable. A critical value was calculated to determine significant difference between two variables in a single population. The chi-square test for independence was used to determine if one of the variables was affected by another variable. For example, if academic standing affects the students' level of satisfaction of the CPVC.

A z-test was also used to determine whether two populations significantly differed for a single categorical characteristic. Percentages of questions 2 to 4 and 10 to 13 were use to determine a $z$-critical value. For there, a $p$-value to determine significant difference was calculated. There were two single categorical characteristic examined; pre-veterinary undergraduate students and upperclassmen students involved at the CPVC. A z- test was used in this research to determine if there is a difference in students who are pre-veterinary undergraduate students or students who are upperclassmen. From this data, conclusions about who to tailor the curriculum around to better meet the needs of the students can be developed.

A significance level of .05 was used to determine significant relationships in student preferences. With a p-value greater than .05, there is no relationship in student preferences. If the $p$-value is below .05 , there is a significant relationship in student preferences.

For questions that asked students to rank species or clinical experiences the data was analyzed by an aggregate ranking method. This ranking was 
formulated by calculating the sum of each option presented to the student. From there the grand totals were ordered from least to greatest thus determining the ranking order of interest. In this particular analysis, the options that received the lowest total represented the options students were most interested in either species or clinical experience.

The data from this study will be presented in tables and graphs for a clear understanding of the information. The data collected in the survey will be used to understand the key importance of the CPVC and the student preferences of clinical experiences and animal species. The results of this study is to assist the animal science department's pre-veterinary science program at Cal Poly to enhance the needs of the students in this program while meeting the needs for their future careers in veterinary medicine.

\section{Assumptions}

This study assumes that the information provided by the sample of Cal Poly students is assumed to be true and accurate. It is assumed that 80 respondents is an accurate representative of the total population of students participating at the CPVC.

Analysis using chi-square test for independence and z-test for population proportion comparison for associations was tested under the assumption that variables are nominal or ordinal data and the groups are independent. 


\section{Limitations}

The results found in this study are representative of the Cal Poly students in which the survey was conducted to. Because Dr. Sprayberry is a first year faculty member in the Animal Science Department at Cal Poly and head veterinary at the CPVC, the research was limited to courses of which Dr. Sprayberry was instructor of. This limited the research to students from Fall 2012, Fall 2013, Winter 2014 and Spring 2014. 


\section{CHAPTER 4}

Development of the Study

Data Collection

The surveys were distributed to Cal Poly college students between April 21, 2014 and May 6, 2014 to 372 students in five different animal science courses. The five courses include ASCI 290- Veterinary Clinic Enterprise Course, ASCI 227- Companion Animal Science, ASCI 229 Anatomy and Physiology of Farm Animals, ASCI 310 Technical Veterinary Skill Course, and ASCI 438 Systemic Animal Physiology. There were 80 completed surveys from the students.

Surveying college students came with its own set of challenges. It was not feasible to survey each individual student who has taken one of the five animal science courses over the past two years. To receive a better response rate; an email was created to introduce the survey and provide a link to the online survey. Some of the students skipped questions or did not fully complete the question because no one was administrating the survey to them individually. In the future, to receive the most complete data, it would be ideal to individually complete the survey with each student each quarter.

\section{Statistical Tests}

The majority of the data received was categorical data. Chi-squared tests of independence were used to determine critical values for Questions17 and 18 . Chi- squared test of independence compare two categorical variables from a 
single population to determine whether there was a significant association between the two variables. In addition to chi-square test of independence, ztests were also used to determine comparison of two population proportions. A ztest of two population proportions determined whether there was a significant difference between two populations when comparing the populations to a single characteristic.

\section{Data Overview}

There were 80 total survey collected. Of the 80 respondents, 74 of them are female and 6 are male.

More than half of respondents, 66 percent are pre-vet undergraduate students and of those students, 51 respondents are females. Table 1 shows the breakdown of students' gender and the respondents' status of being a pre-vet undergraduate student.

Table 1. Gender breakdown of pre-vet undergraduate respondents

\begin{tabular}{|l|l|l|l|}
\hline Gender & \multicolumn{1}{l}{$\begin{array}{l}\text { Number of } \\
\text { Pre-Vet Students }\end{array}$} & $\begin{array}{l}\text { Number of } \\
\text { Non-Pre-Vet } \\
\text { Students }\end{array}$ & $\begin{array}{l}\text { Percent of Total } \\
(\mathbf{N}=80)\end{array}$ \\
\hline Male & 2 & 4 & $7 \%$ \\
\hline Female & 51 & 23 & $93 \%$ \\
\hline
\end{tabular}

The majority of respondents, 35 percent, are juniors at Cal Poly, and the academic standing least surveyed were graduate students. Table 2 illustrates the academic standing breakdown of the survey respondents. 
Table 2. Respondents' academic standing breakdown

\begin{tabular}{|l|l|l|}
\hline Grade & $\begin{array}{l}\text { Number of } \\
\text { Respondents }\end{array}$ & $\begin{array}{l}\text { Percent of Total } \\
\text { (N=80) }\end{array}$ \\
\hline Freshman & 7 & $9 \%$ \\
\hline Sophomore & 16 & $20 \%$ \\
\hline Junior & 28 & $35 \%$ \\
\hline Senior & 26 & $33 \%$ \\
\hline Graduate student & 3 & $4 \%$ \\
\hline
\end{tabular}

When asked about the students current place of residence, more than half (59 percent) of respondents reside off the Cal Poly campus grounds. The other 41 percent of respondents live on campus either in dormitories, campus apartments, or animal science facility resident housing. Table 3 presents the breakdown of respondent's residential location.

Table 3. Respondent current residence breakdown

\begin{tabular}{|l|l|l|}
\hline Current Residence & \multicolumn{1}{|l|}{$\begin{array}{l}\text { Number of } \\
\text { Respondents }\end{array}$} & $\begin{array}{l}\text { Percent of Total } \\
\text { (N=80) }\end{array}$ \\
\hline On Campus & 33 & $41 \%$ \\
\hline Off Campus & 47 & $59 \%$ \\
\hline
\end{tabular}

When asked about college funding, 51 percent of respondents reported to use financial aid to pay for college. Thirty percent of total respondents said to be using scholarships to fund college needs and 53 percent of respondents reported 
using family or private funds to pay for college. When asked if respondents own pets 96 percent indicated they or their family owns a pet or multiple pets.

The respondents were asked if their family is directly involved in agriculture and 91 percent of respondents reported that their family is not involved in agriculture. Six percent of respondents indicated that their families are farmers or ranchers while 3 percent stated that their family is directly involved in veterinary medicine. Two other choices were presented to respondents, but no one reported to be directly involved in agriculture as an agricultural educator or state representative for the agriculture industry.

The majority, 93 percent, of respondents reported to be an animal science major at Cal Poly. The other 7 percent of respondents indicated their major to be dairy science in the College of Agriculture, Food \& Environmental Sciences. When asked about career plans after graduation from Cal Poly, a majority of respondents ( 65 percent) plan on attending a veterinary medical school. Eleven percent of student respondents do not plan on attending any program after graduation. Table 4 shows a breakdown of the respondents' plans after graduation from Cal Poly. 
Table 4. Respondent program plans for after graduation breakdown.

\begin{tabular}{|c|c|c|}
\hline Program & Number of Respondents & $\begin{array}{l}\text { Percent of Total } \\
(\mathrm{N}=80)\end{array}$ \\
\hline Veterinary Medical School & 52 & $65 \%$ \\
\hline Master Graduate Program & 13 & $16 \%$ \\
\hline $\begin{array}{l}\text { Doctoral Program (other } \\
\text { than vet school) }\end{array}$ & 2 & $3 \%$ \\
\hline $\begin{array}{l}\text { Registered Veterinary } \\
\text { Technician }\end{array}$ & 4 & $5 \%$ \\
\hline $\begin{array}{l}\text { Not planning on attending } \\
\text { any program }\end{array}$ & 9 & $11 \%$ \\
\hline
\end{tabular}

Of the 80 respondents surveyed, 57 respondents have or are currently taking Animals Science 229- Anatomy and Physiology of Farm Animals. Four percent of respondents were involved in the CPVC by being student lab managers while 6 percent of respondents reported to volunteer at the CPVC. A breakdown of student involvement at the CPVC is illustrated below in Figure 1. 


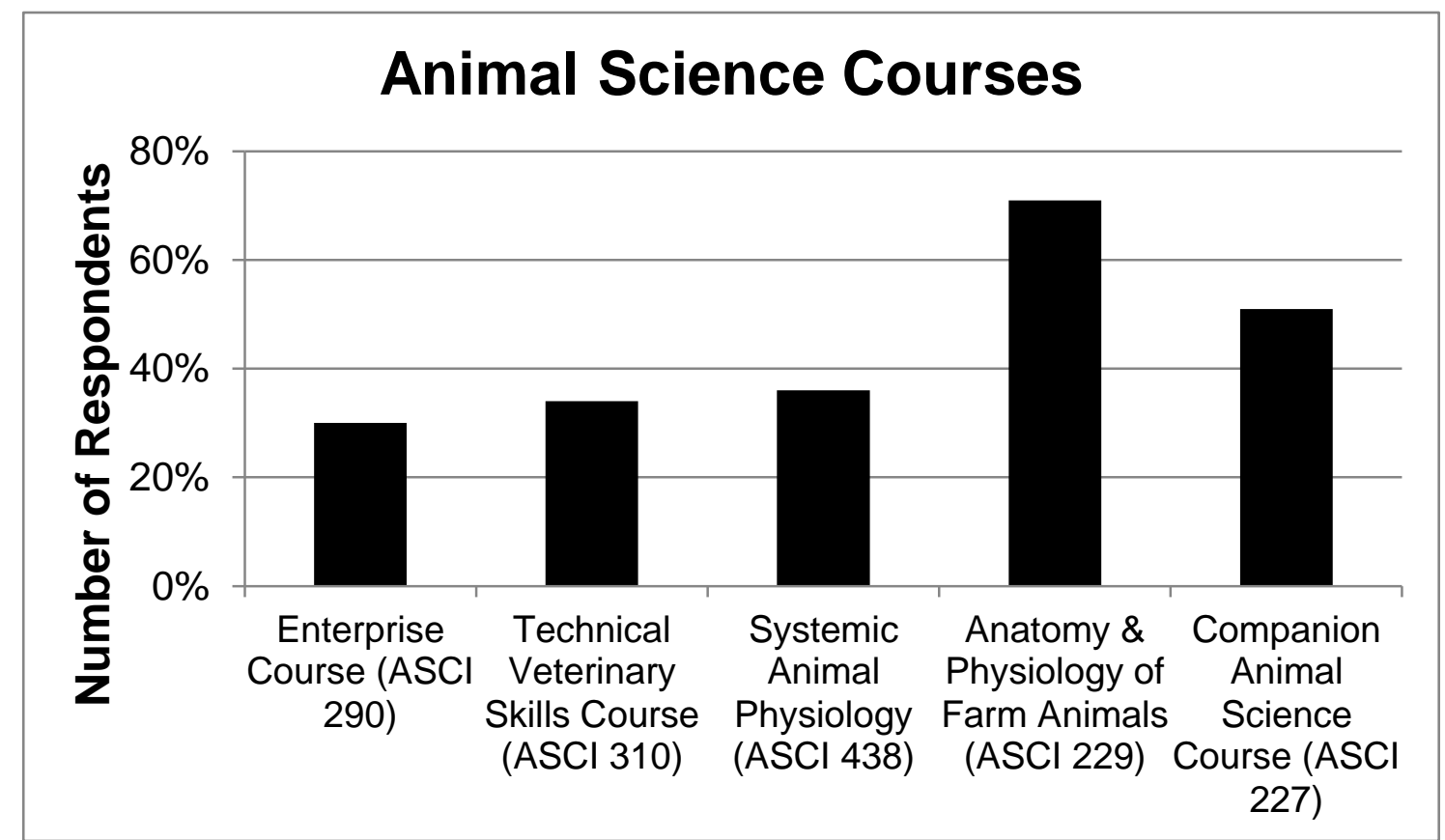

Figure 1. Animal Science courses taken by respondents.

The majority of respondents, 73 percent, spend two to four hours a week at the CPVC in any given quarter. Just under half of respondents, 45 percent, have participated at the CPVC for two quarters while 11 percent of respondents have spent five or more quarters at the CPVC.

When asked to rate the following statement, "the Cal Poly Veterinary Clinic hands-on learning environment is preparing me for my future educational goals," the majority of respondents, 64 percent, agreed with this statement. Thirty- three percent of respondents indicated that they strongly agreed with the previous statement while 4 percent reported to be neutral about the statement.

The majority of respondents, 54 percent, agreed with a statement that said, "the hands-on experience at the Cal Poly Veterinary Clinic has met my expectations for the clinic." One third of respondents, 33 percent, indicated they 
strongly agreed with the previous statement. Nine percent of students reported to be neutral while five percent disagreed with the above statement.

Overall 50 percent of respondents are 'very likely' to recommend the CPVC to other students. However, two respondents did report that they would not recommend the CPVC to other students. Table 5 shows a breakdown of students' likelihood to recommend the CPVC.

Table 5. Respondent likelihood to recommend the CPVC.

\begin{tabular}{|l|l|l|}
\hline Likelihood & $\begin{array}{l}\text { Number of } \\
\text { Respondent }\end{array}$ & $\begin{array}{l}\text { Percent of Total } \\
(\mathbf{N = 8 0 )}\end{array}$ \\
\hline Extremely Likely & 28 & $35 \%$ \\
\hline Very Likely & 40 & $50 \%$ \\
\hline Moderately Likely & 8 & 10 \\
\hline Slightly Likely & 2 & $3 \%$ \\
\hline Not Likely At All & 2 & $3 \%$ \\
\hline
\end{tabular}

The respondents were given a list of ten clinical experiences to rank in order of preference of most likely to participate to least likely to participate. Anesthetic surgery was ranked the most likely to participate by the respondents. Additionally, the respondents were, also, given a list of eleven species to ranks in order of preference of most interested in to least interested. Small animals ranked highest in most interested species by the respondents. Table 6 and Table 7 illustrate the ranking of all the clinical experiences and species. 
Table 6. Rank of clinical experiences.

\begin{tabular}{|ll|}
\hline Rank & Clinical Experience \\
\hline $\mathbf{1}$ & Anesthetic Surgery \\
\hline $\mathbf{2}$ & Physical Examination \\
\hline $\mathbf{3}$ & Vaccine Administration \\
\hline $\mathbf{4}$ & Breeding/ Reproduction \\
\hline $\mathbf{5}$ & Nutrition Management \\
\hline $\mathbf{6}$ & Wound Care Management \\
\hline $\mathbf{7}$ & Animal Handling \& Resistant \\
\hline $\mathbf{8}$ & Necropsy Procedure \\
\hline $\mathbf{9}$ & Pharmacology \\
\hline $\mathbf{1 0}$ & Herd Health Programs \\
\hline
\end{tabular}

Table 7. Rank of Animal Species.

\begin{tabular}{|ll|}
\hline Rank & Species \\
\hline $\mathbf{1}$ & Small Animals \\
\hline $\mathbf{2}$ & Mixed Practice \\
\hline $\mathbf{3}$ & Wildlife \\
\hline $\mathbf{4}$ & Equine \\
\hline $\mathbf{5}$ & Exotics \\
\hline $\mathbf{6}$ & Zoo Animals \\
\hline $\mathbf{7}$ & Food Animals \\
\hline $\mathbf{8}$ & Lab Animals \\
\hline $\mathbf{9}$ & Dairy \\
\hline $\mathbf{1 0}$ & Avian \\
\hline $\mathbf{1 1}$ & Fish \\
\hline
\end{tabular}

The majority of respondents, 95 percent, reported that hands-on learning is a strength of the CPVC. Eighty- three percent of respondents, also, reported that practical animal exposure is a strength of the CPVC. Figure 2 below indicates the different strengths of the CPVC reported by the respondents. 


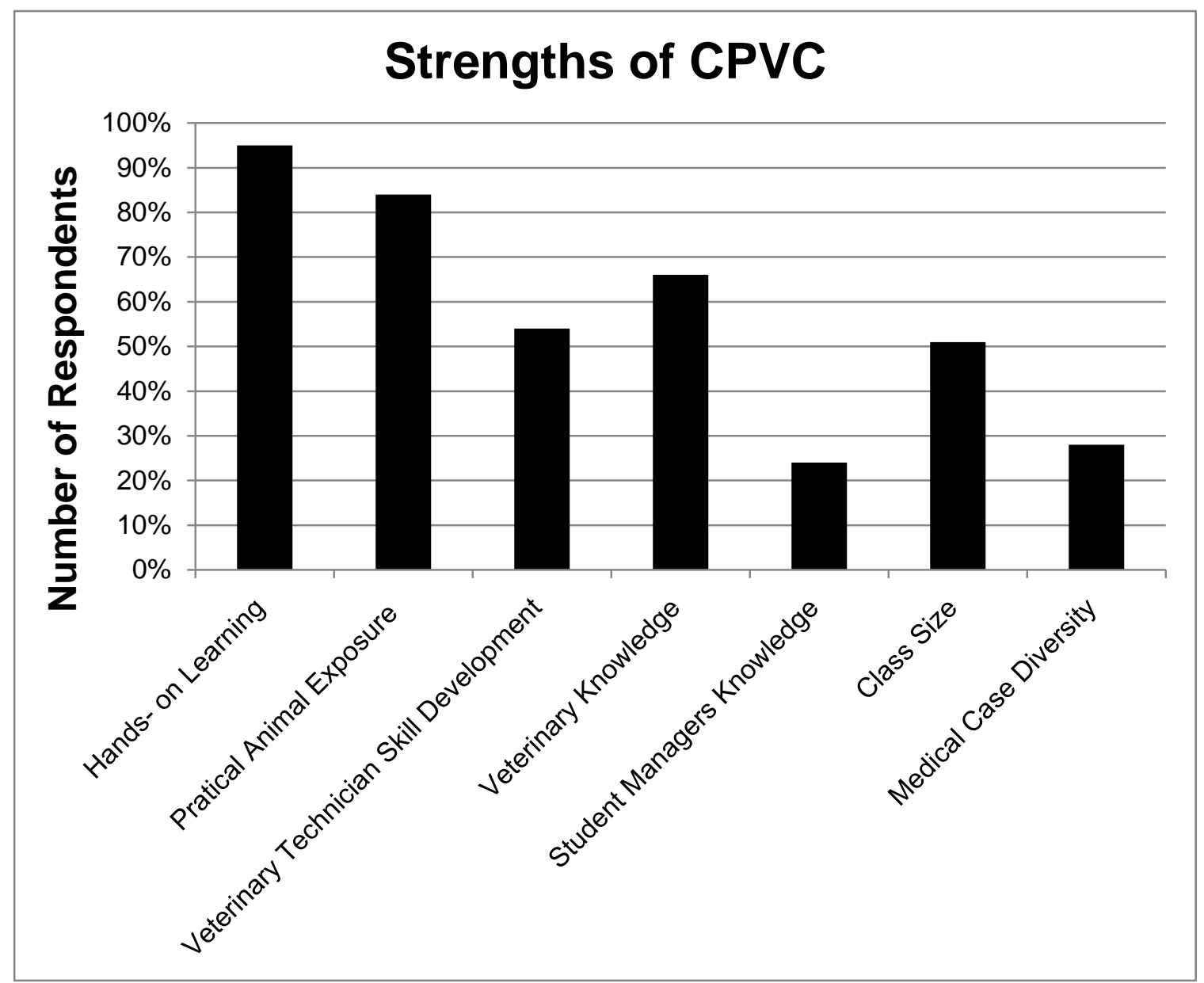

Figure 2. CPVC Strengths according to the respondents.

When asked about the future for the CPVC, 89 percent of respondents 
reported they would like to see more diverse cases and animals treatments at the CPVC. Sixty- four percent of respondents indicated they would like more diverse courses offered as well. An overall breakdown of changes the respondents would like to see in the future for CPVC in illustrated in Figure 3.

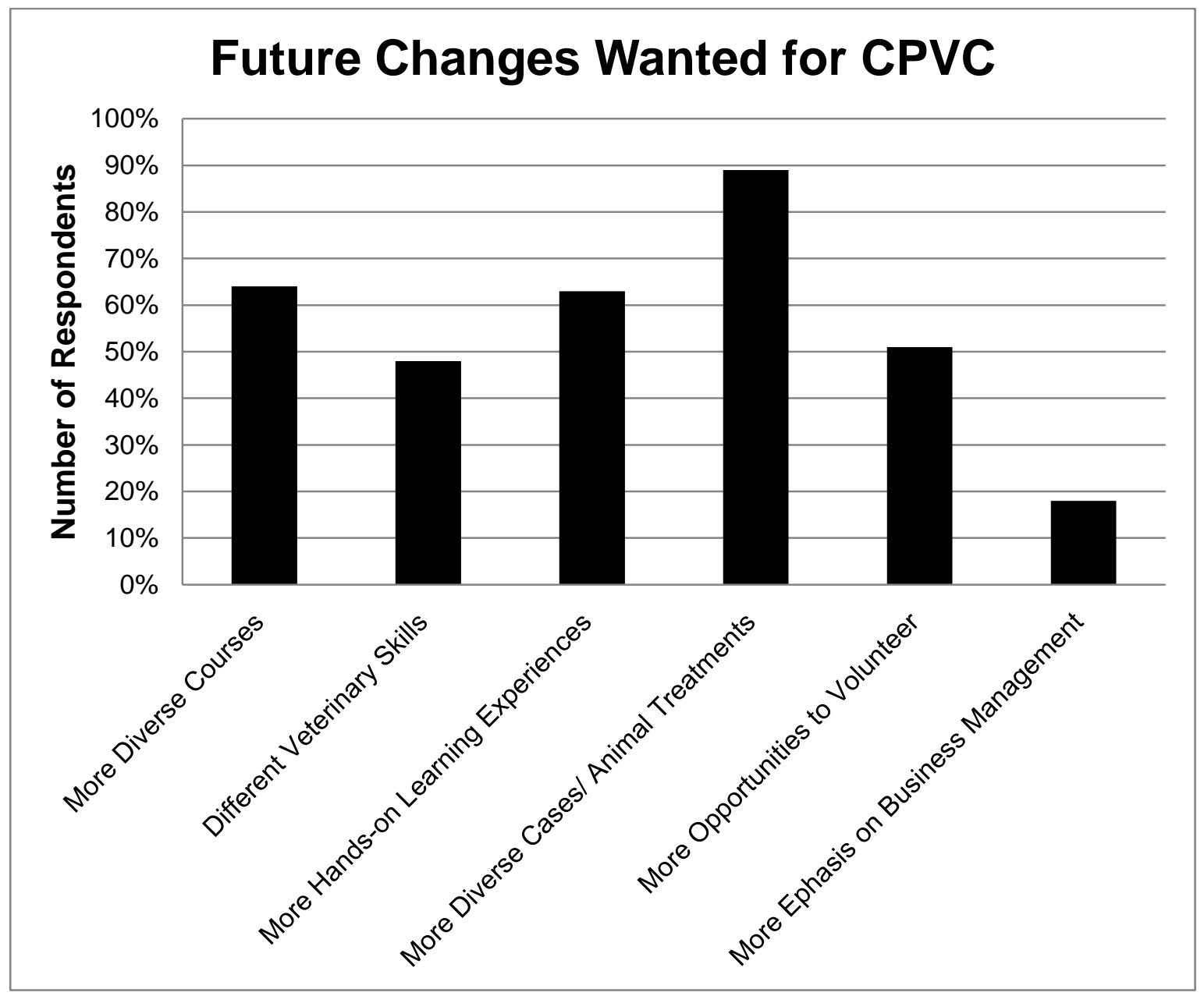

Figure 3. Future changes for CPVC according to the respondents

The respondents were given eight benefits of the CPVC and asked to rate the benefits on levels of importance or levels of satisfaction. Respondents reported that hands-on learning, practical animal exposure, preparation for 
veterinary medical school, veterinary technician skill development, and the veterinarians are extremely important benefits of the CPVC. The other three benefits were reported to be very important to the CPVC. Table 8 and Table 9 show the breakdown of the level of importance each benefit was rated at by the respondents.

Table 8. Respondents breakdown of rating of extremely important benefits

\begin{tabular}{|l|l|l|}
\begin{tabular}{|l|l|} 
Extremely \\
Important
\end{tabular} & \multicolumn{1}{l}{$\begin{array}{l}\text { Number of } \\
\text { Respondents }\end{array}$} & \multicolumn{1}{l|}{$\begin{array}{l}\text { Percent of Total } \\
\text { (N=80) }\end{array}$} \\
\hline $\begin{array}{l}\text { Hands-on } \\
\text { Learning }\end{array}$ & 56 & $70 \%$ \\
\hline $\begin{array}{l}\text { Practical } \\
\text { Animal } \\
\text { Exposure }\end{array}$ & 49 & $61 \%$ \\
\hline $\begin{array}{l}\text { Preparation } \\
\text { for Veterinary } \\
\text { Medical } \\
\text { School }\end{array}$ & 51 & $62 \%$ \\
\hline $\begin{array}{l}\text { Veterinary } \\
\text { Technician } \\
\text { Skill } \\
\text { Development }\end{array}$ & 41 & $51 \%$ \\
\hline Veterinarians & 45 & $56 \%$ \\
\hline
\end{tabular}

Table 9. Respondents breakdown of rating of very important benefits.

\begin{tabular}{|l|l|l|}
$\begin{array}{l}\text { Very } \\
\text { Important }\end{array}$ & \multicolumn{1}{l}{$\begin{array}{l}\text { Number of } \\
\text { Respondents }\end{array}$} & \multicolumn{1}{l|}{$\begin{array}{l}\text { Percent of Total } \\
(\mathbf{N}=80)\end{array}$} \\
\hline $\begin{array}{l}\text { Resume } \\
\text { Building }\end{array}$ & 32 & $40 \%$ \\
\hline $\begin{array}{l}\text { Teaching } \\
\text { Methods }\end{array}$ & 37 & $46 \%$ \\
\hline $\begin{array}{l}\text { Student } \\
\text { Managers }\end{array}$ & 38 & $48 \%$ \\
\hline
\end{tabular}

Respondents reported to be extremely satisfied with the CPVC's use of practical animal exposure, preparation for veterinary medical school, veterinary 
technician skill development, the veterinarians, and the student managers. Table 10 and Table 11 show the breakdown of levels of satisfaction each factor was rated at by the respondents. A deeper analysis of these questions is below.

Table 10. Respondents breakdown of rating of extremely satisfied factors.

\begin{tabular}{|l|l|l|}
\hline $\begin{array}{l}\text { Extremely } \\
\text { Satisfied }\end{array}$ & \multicolumn{1}{|l|}{$\begin{array}{l}\text { Number of } \\
\text { Respondents }\end{array}$} & \multicolumn{1}{|c|}{$\begin{array}{l}\text { Percent of Total } \\
\text { (N=80) }\end{array}$} \\
\hline $\begin{array}{l}\text { Practical } \\
\text { Animal } \\
\text { Exposure }\end{array}$ & 35 & $44 \%$ \\
\hline $\begin{array}{l}\text { Preparation for } \\
\text { Veterinary } \\
\text { Medical School }\end{array}$ & 32 & $40 \%$ \\
\hline $\begin{array}{l}\text { Veterinary } \\
\text { Technician Skill } \\
\text { Development }\end{array}$ & 31 & $39 \%$ \\
\hline Veterinarians & 40 & $50 \%$ \\
\hline $\begin{array}{l}\text { Student } \\
\text { Managers }\end{array}$ & 31 & $39 \%$ \\
\hline
\end{tabular}

Table 11. Respondents breakdown of very satisfied of factors.

\begin{tabular}{|l|l|l|}
\hline $\begin{array}{l}\text { Very } \\
\text { Satisfied }\end{array}$ & \multicolumn{1}{|l|}{$\begin{array}{l}\text { Rumber of } \\
\text { Respondents }\end{array}$} & $\begin{array}{l}\text { Percent of Total } \\
(\mathbf{N}=80)\end{array}$ \\
\hline $\begin{array}{l}\text { Resume } \\
\text { Building }\end{array}$ & 33 & $41 \%$ \\
\hline $\begin{array}{l}\text { Teaching } \\
\text { Methods }\end{array}$ & 38 & $48 \%$ \\
\hline $\begin{array}{l}\text { Hands-on } \\
\text { Learning }\end{array}$ & 35 & $44 \%$ \\
\hline
\end{tabular}

\section{Expectations of the CPVC}

In a short paragraph, respondents discussed if the CPVC was meeting their (the students) expectations. The responses were grouped into five different categories; facility staff, hands-on learning, animal exposure, the CPVC building, and overall expectations. The first category looked at the facility's staff including 
the veterinarians and student managers. Respondents indicated that both are helpful during labs and students managers are "super nice too!"

Overall respondents wrote positive comments about the CPVC's handson learning environment including "the clinic offers great hands-on experience" and the clinic is "very hands-on." When discussing the hands-on learning environment of the CPVC, one respondent wrote:

"The hands-on learning experiences I had at the CPVC gave me the skills and confidence I need as a veterinary student. I had the opportunity to not only learn but also teach other students at the vet clinic. The knowledge and skills I gained while there are so unique, and really set me apart as a veterinary school applicant."

In another category analyzed, respondents positively discussed how seeing the daily exposure of a functioning animal clinic is one way the CPVC is meeting the students' expectations. Respondents commented that there are a lot of interesting animal cases and students have opportunities to work with all kinds of animals, not just agriculture animals. One student describes his or her expectations of animal exposure as:

"Gaining exposure to the daily responsibilities that the Cal Poly vet clinic has helped me become more familiar with the tasks and challenges a functioning veterinary clinic must tend to on a regular basis. Additionally, the vet clinic has served as a resource and opportunity to gain veterinary 
experience through labs, work opportunities, and other instances where I have the chance to take part in veterinary procedures."

Respondents do not believe that the physical infrastructure of the CPVC is meeting their expectations. Most respondents noted the limitation of school funding given to the CPVC, but many respondents wrote about how old the building is and the many updates needed at the CPVC. One student wrote, "the vet clinic could definitely use an updated facility, but they are doing amazing things with what they have."

Overall, respondents feel the CPVC is meeting their expectations, even with the outdated infrastructure and equipment. One respondent commented on his or her time working at the CPVC:

"Working at the clinic has allowed me to gain a strong understanding and practical experience of running a small business. Through this experience I have learned the day to day operations of a veterinary practice by scheduling appointments, speaking with clients, helping with appointments and surgeries, paying bills, as well as many other duties. This experience has exceeded by expectations. I do admit that the building itself, as well as some of the equipment is old and is in need of replacement. However, I do realize that funding is limited and this I know not to expect much."

Another respondent presents a good summary of all the respondents and wrote:

"Cal Poly Veterinary Clinic is meeting my expectations in that we are able to learn how a clinic works through classes on campus rather than solely 
relying in looking for experience and exposure to the clinic environment through outside sources. The clinic has most everything an off campus could (it's just a little older) which is great for learning. Having small class sizes has been one of the best benefits because it gives all the students an opportunity to get hands-on experience with the tools we have available."

Pre-Veterinary Undergraduate Students and Academic Class Standings A deeper analysis of respondents came from Question 9, indicating if the respondent was a pre-veterinary (pre-vet) undergraduate student. The survey shows that 66 percent of respondents indicated they are pre-vet undergraduate students at Cal Poly. This category was chosen because it represents the population that would like to pursue a career in veterinary medicine and therefore use the CPVC while an undergraduate.

The second category came from Question 3, indicating the academic standing of the respondents who completed the survey. The survey shows that 9 percent of respondents are freshmen, 20 percent are sophomores, 35 percent are juniors, 33 percent are seniors, and 4 percent are graduate students. The analysis focuses on students who are juniors, seniors, or graduate students. This category was chosen because it represents the population that has taken more of the courses offered at the CPVC and could have spent more time at the CPVC throughout their years at Cal Poly. 
Analysis

Z-tests were conducted on categorical data to determine the comparison of two population proportions. The first population to be compared was students who are pre-vet undergraduate students and non-pre-vet students (Tables 1219). The second group to be compared was upperclassmen and underclassmen students (Tables 20-27).

Table 12 shows the gender breakdown of the respondents that are pre-vet undergraduate students which indicates that of the 74 female respondents, $69 \%$ are pre-vet students.

$\mathrm{H}_{0}$ : percent of female pre-vet students $=$ percent of pre-vet male students

$\mathrm{H}_{\mathrm{a}}$ : percent of female pre-vet students $\neq$ percent of pre-vet male students

The null hypothesis fails to be rejected concluding no difference between the percent of female pre-vet students and percent of male pre-vet students.

Table 12. Gender breakdown of Pre-vet undergraduate students.

\begin{tabular}{|l|l|l|l|l|} 
Gender & \multicolumn{1}{|l}{$\begin{array}{l}\text { Percentage of } \\
\text { Pre-Vet } \\
\text { Students }\end{array}$} & $\begin{array}{l}\text { Percentage } \\
\text { of } \\
\text { Non-Pre-Vet } \\
\text { Students }\end{array}$ & $\begin{array}{l}\text { Number of } \\
\text { Respondents }\end{array}$ & P-Value \\
\hline Female & $69 \%$ & $21 \%$ & 74 & 0.076 \\
\hline Male & $33 \%$ & $67 \%$ & 6 & \\
\hline
\end{tabular}

Table 13 indicates the academic standing breakdown of the respondents who are pre-vet students. Of the freshmen students, 86 percent are pre-vet students. However, only 33 percent of the graduate students are pre-vet. 
$H_{0}$ : percent of pre-vet freshmen $=$ percent of pre-vet sophomores $=$ percent of pre-vet juniors $=$ percent of pre-vet seniors $=$ percent of pre-vet graduate students

$H_{a}$ : percent of pre-vet freshmen $\neq$ percent of pre-vet sophomores $\neq$ percent of pre-vet juniors $\neq$ percent of pre-vet seniors $\neq$ percent of pre-vet graduate students

The null hypothesis fails to be rejected concluding no difference in percent of different pre-vet academic standing students.

Table 13. Academic standing breakdown of Pre-vet undergraduate students.

\begin{tabular}{|l|l|l|l|l|}
\hline $\begin{array}{l}\text { Academic } \\
\text { Standing }\end{array}$ & $\begin{array}{l}\text { Percentage of } \\
\text { Pre-Vet } \\
\text { Students }\end{array}$ & \multicolumn{1}{|c|}{$\begin{array}{l}\text { Percentage of } \\
\text { Non-Pre-Vet } \\
\text { Students }\end{array}$} & \multicolumn{2}{|l}{$\begin{array}{l}\text { Number of } \\
\text { Respondents }\end{array}$} \\
\hline Freshman & $86 \%$ & $14 \%$ & 7 & 0.479 \\
\hline Sophomore & $56 \%$ & $44 \%$ & 16 & \\
\hline Junior & $68 \%$ & $32 \%$ & 28 & \\
\hline Senior & $69 \%$ & $21 \%$ & 26 & \\
\hline $\begin{array}{l}\text { Graduate } \\
\text { Student }\end{array}$ & $33 \%$ & $67 \%$ & 3 & \\
\hline
\end{tabular}

Table 14 illustrates the breakdown of respondents' current place of residence who are pre-vet students. Of the pre-vet students, seventy- nine percent live on campus while forty-three percent live off campus.

$\mathrm{H}_{0}$ : percent of pre-vet live on campus = percent of pre-vet live off campus

$\mathrm{H}_{\mathrm{a}}$ : percent of pre-vet live on campus $\neq$ percent of pre-vet live off campus 
The null hypothesis is rejected concluding there is a difference in percent of pre-vet students living on campus and pre-vet students living off campus.

Table 14. Current residence breakdown of Pre-vet undergraduate students.

\begin{tabular}{|l|l|l|l|l|}
\hline $\begin{array}{l}\text { Current } \\
\text { Residence }\end{array}$ & \multicolumn{1}{l}{$\begin{array}{l}\text { Percentage of } \\
\text { Pre-Vet } \\
\text { Students }\end{array}$} & $\begin{array}{l}\text { Percentage of } \\
\text { Non-Pre-Vet } \\
\text { Students }\end{array}$ & $\begin{array}{l}\text { Number of } \\
\text { Respondents }\end{array}$ & P-Value \\
\cline { 1 - 4 } On Campus & $79 \%$ & $21 \%$ & 33 & $0.047^{\star \star}$ \\
\hline Off Campus & $43 \%$ & $57 \%$ & 47 & \\
\hline
\end{tabular}

Table 15 indicates the college major breakdown of the respondents who are pre-vet students. Of animal science majors, 66 percent are pre-vet while $67 \%$ of dairy science majors are pre-vet.

$\mathrm{H}_{0}$ : percent of pre-vet animal science major = percent of pre-vet dairy science major

$\mathrm{H}_{\mathrm{a}}$ : percent of pre-vet animal science major $\neq$ percent of pre-vet dairy science major

The null hypothesis fails to be rejected concluding no difference in percent of pre-vet animal science major and pre-vet dairy science major.

Table 15. College major breakdown of Pre-vet undergraduate students.

\begin{tabular}{|l|l|l|l|l|}
\hline College Major & $\begin{array}{l}\text { Percentage of } \\
\text { Pre-Vet } \\
\text { Students }\end{array}$ & $\begin{array}{l}\text { Percentage of } \\
\text { Non-Pre-Vet } \\
\text { Students }\end{array}$ & \multicolumn{2}{|l|}{$\begin{array}{l}\text { Number of } \\
\text { Respondents }\end{array}$} \\
Animal Science & $66 \%$ & $34 \%$ & 74 & 0.982 \\
\hline Dairy Science & $67 \%$ & $33 \%$ & 6 & \\
\hline
\end{tabular}


As shown in Table 16, 76 percent of pre-vet respondents have or are currently taking Animal Science 229 course- Anatomy and Physiology of Farm Animals. Eight percent of pre-vet undergraduate students indicate they volunteer at CPVC compared to 4 percent of non-pre-vet undergraduate students. Figure 4 displays the breakdown of pre-vet undergraduate students and which courses they have taken or are currently taking at the CPVC.

$\mathrm{H}_{0}$ : percent of pre-vet student involvement= percent of non-pre-vet student involvement

$\mathrm{H}_{\mathrm{a}}$ : percent of pre-vet student involvement $\neq$ percent of non-pre-vet student involvement

The null hypothesis fails to be rejected concluding no difference in percent of pre-vet student and percent of non-pre-vet student when examining involvement at the CPVC.

Table 16. Involvement of Pre-vet undergraduate students.

\begin{tabular}{|c|c|c|c|c|}
\hline Involvement & $\begin{array}{l}\text { Percentage of } \\
\text { Pre-Vet } \\
\text { Students }\end{array}$ & $\begin{array}{l}\text { Percentage of } \\
\text { Non-Pre-Vet } \\
\text { Students }\end{array}$ & $\begin{array}{l}\text { Number of } \\
\text { Respondents }\end{array}$ & P-Value \\
\hline ASCI 290 & $34 \%$ & $22 \%$ & 24 & 0.279 \\
\hline ASCl 227 & $49 \%$ & $56 \%$ & 41 & 0.582 \\
\hline ASCl 310 & $34 \%$ & $33 \%$ & 27 & 0.955 \\
\hline ASCl 229 & $76 \%$ & $63 \%$ & 57 & 0.242 \\
\hline ASCl 438 & $32 \%$ & $44 \%$ & 29 & 0.277 \\
\hline $\begin{array}{l}\text { Student Lab } \\
\text { Teacher }\end{array}$ & $4 \%$ & $4 \%$ & 3 & 0.988 \\
\hline Volunteer & $7 \%$ & $4 \%$ & 5 & 0.502 \\
\hline
\end{tabular}




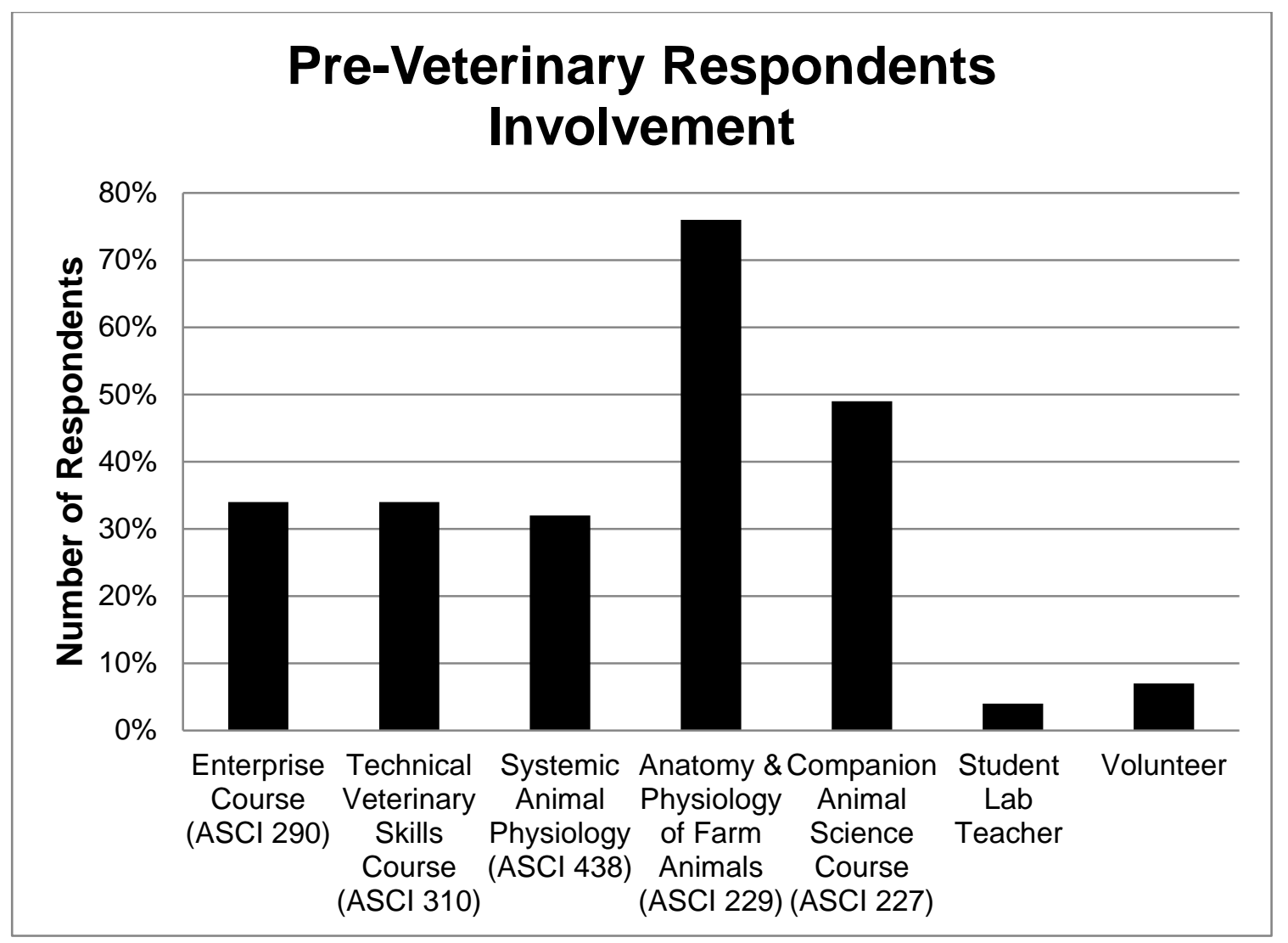

Figure 4. Pre-vet undergraduate students' involvement at the CPVC.

Table 17 breaks down the number of hours typically spent at the CPVC of the pre-vet undergraduate students. Of the pre-vet students, seventy- four percent spend 2.1 to 4 hours a week at the CPVC.

$\mathrm{H}_{\mathrm{o}}$ : percent of hours spent by pre-vet students= percent of hours spent by non-pre-vet students

$H_{a}$ : percent of hours spent by pre-vet students $\neq$ percent of hours spent by non-pre-vet students 
The null hypothesis fails to be rejected concluding no difference in percent of pre-vet student and percent of non-pre-vet student when examining average time spent at the CPVC.

Table 17. Hours spent at the CPVC by Pre-vet undergraduate students.

\begin{tabular}{|c|c|c|c|c|}
\hline Hours & $\begin{array}{l}\text { Percentage of } \\
\text { Pre-Vet } \\
\text { Students }\end{array}$ & $\begin{array}{l}\text { Percentage of } \\
\text { Non-Pre-Vet } \\
\text { Students }\end{array}$ & $\begin{array}{l}\text { Number of } \\
\text { Respondents }\end{array}$ & P-Value \\
\hline $0-2.0 \mathrm{hrs}$ & $4 \%$ & $11 \%$ & 5 & \multirow[t]{6}{*}{0.487} \\
\hline $2.1-4.0 \mathrm{hrs}$ & $74 \%$ & $70 \%$ & 58 & \\
\hline $4.1-6.0 \mathrm{hrs}$ & $17 \%$ & $11 \%$ & 12 & \\
\hline $6.1-8.0 \mathrm{hrs}$ & $2 \%$ & $0 \%$ & 1 & \\
\hline $8.1-10.0 \mathrm{hrs}$ & $0 \%$ & $4 \%$ & 1 & \\
\hline $10.1+$ hours & $4 \%$ & $4 \%$ & 3 & \\
\hline
\end{tabular}

Table 18 shows the number of quarters pre-vet undergraduate students have spent at the CPVC. Of the pre-vet students, 41 percent have spent two quarters at the CPVC.

$\mathrm{H}_{0}$ : percent of quarters spent by pre-vet students= percent of quarters spent by non-pre-vet students

$H_{a}$ : percent of quarters spent by pre-vet students $\neq$ percent of quarters spent by non-pre-vet students

The null hypothesis fails to be rejected concluding no difference in percent of pre-vet student and percent of non-pre-vet student when examining number of quarters spent at the CPVC. 
Table 18. Number of quarters spent at the CPVC by Pre-vet undergraduate students.

\begin{tabular}{|c|c|c|c|c|}
\hline Quarters & $\begin{array}{l}\text { Percentage of } \\
\text { Pre-Vet } \\
\text { Students }\end{array}$ & $\begin{array}{l}\text { Percentage of } \\
\text { Non-Pre-Vet } \\
\text { Students }\end{array}$ & $\begin{array}{l}\text { Number of } \\
\text { Respondents }\end{array}$ & P-Value \\
\hline 1 & $21 \%$ & $15 \%$ & 15 & \multirow[t]{5}{*}{0.859} \\
\hline 2 & $41 \%$ & $52 \%$ & 36 & \\
\hline 3 & $24 \%$ & $22 \%$ & 19 & \\
\hline 4 & $2 \%$ & $0 \%$ & 1 & \\
\hline $5+$ & $11 \%$ & $11 \%$ & 9 & \\
\hline
\end{tabular}

Illustrated in Table 19, of pre-vet students, 98 percent, plan on attending veterinary medical school after graduation from Cal Poly.

$\mathrm{H}_{0}$ : percent of pre-vet veterinary medical school= percent of pre-vet master graduate program $=$ percent of pre-vet doctoral program $=$ percent of prevet $\mathrm{RVT}=$ percent of pre-vet no plans

$\mathrm{H}_{\mathrm{a}}$ : percent of pre-vet veterinary medical school $\neq$ percent of pre-vet master graduate program $\neq$ percent of pre-vet doctoral program $\neq$ percent of prevet RVT $\neq$ percent of pre-vet no plans

The null hypothesis is rejected concluding there is difference in percent of pre-vet students when comparing programs students plan on attending after graduation. 
Table 19. Programs Pre- Veterinary undergraduate students plan on attending after graduation.

\begin{tabular}{|c|c|c|c|c|}
\hline Programs & $\begin{array}{l}\text { Percentage of } \\
\text { Pre-Vet } \\
\text { Students }\end{array}$ & $\begin{array}{l}\text { Percentage of } \\
\text { Non-Pre-Vet } \\
\text { Students }\end{array}$ & $\begin{array}{l}\text { Number of } \\
\text { Respondents }\end{array}$ & P-Value \\
\hline $\begin{array}{l}\text { Veterinary } \\
\text { Medical } \\
\text { School }\end{array}$ & $98 \%$ & $2 \%$ & 52 & \multirow[t]{5}{*}{$0.00^{\star \star}$} \\
\hline $\begin{array}{l}\text { Master } \\
\text { Graduate } \\
\text { Program }\end{array}$ & $8 \%$ & $92 \%$ & 13 & \\
\hline $\begin{array}{l}\text { Doctoral } \\
\text { Program } \\
\text { (other than vet } \\
\text { school) }\end{array}$ & $0 \%$ & $100 \%$ & 2 & \\
\hline $\begin{array}{l}\text { Registered } \\
\text { Veterinary } \\
\text { Technician }\end{array}$ & $0 \%$ & $100 \%$ & 4 & \\
\hline $\begin{array}{l}\text { Not planning } \\
\text { on attending } \\
\text { any program }\end{array}$ & $11 \%$ & $89 \%$ & 9 & \\
\hline
\end{tabular}

Table 20 shows the gender breakdown of respondents that are upperclassmen students. Of the upperclassmen students, 70 percent are female while 83 percent are male students.

$\mathrm{H}_{\mathrm{o}}$ : percent of female upperclassmen = percent of male upperclassmen

$H_{a}$ : percent of female upperclassmen $\neq$ percent of male upperclassmen

The null hypothesis fails to be rejected concluding no difference between the percent of female upperclassmen students and percent of male upperclassmen students. 
Table 20. Gender breakdown of upperclassmen students.

\begin{tabular}{|c|c|c|c|c|}
\hline Gender & $\begin{array}{l}\text { Percentage of } \\
\text { Upperclassmen }\end{array}$ & $\begin{array}{l}\text { Percentage of } \\
\text { Underclassmen }\end{array}$ & $\begin{array}{l}\text { Number of } \\
\text { Respondents }\end{array}$ & P-Value \\
\hline Female & $70 \%$ & $30 \%$ & 74 & \multirow[t]{2}{*}{0.497} \\
\hline Male & $83 \%$ & $17 \%$ & 6 & \\
\hline
\end{tabular}

Table 21 illustrates the pre-vet undergraduate student breakdown of the respondents who are upperclassmen at Cal Poly. Of the 53 pre-vet respondents, 72 percent are upperclassmen.

$\mathrm{H}_{0}$ : percent of pre-vet upperclassmen = percent of non-pre-vet upperclassmen

$H_{a}$ : percent of pre-vet upperclassmen $\neq$ percent of non-pre-vet

The null hypothesis fails to be rejected concluding no difference in percent of upperclassmen pre-vet students and upperclassmen non-pre-vet students.

Table 21. Pre-vet undergraduate student breakdown of upperclassmen students.

\begin{tabular}{|c|c|c|c|c|}
\hline $\begin{array}{l}\text { Pre-vet } \\
\text { Students }\end{array}$ & $\begin{array}{l}\text { Percentage of } \\
\text { Upperclassmen }\end{array}$ & $\begin{array}{l}\text { Percentage of } \\
\text { Underclassmen }\end{array}$ & $\begin{array}{l}\text { Number of } \\
\text { Respondents }\end{array}$ & P-Value \\
\hline Yes & $72 \%$ & $28 \%$ & 53 & 0.901 \\
\hline No & $70 \%$ & $30 \%$ & 27 & \\
\hline
\end{tabular}

Table 22 indicates the current place of residence breakdown of respondents who are upperclassmen undergraduates at Cal Poly. Of the upperclassmen students, 45 percent live on campus while 89 percent live off campus. 
$\mathrm{H}_{0}$ : percent of upperclassmen live on campus = percent of upperclassmen live off campus

$H_{a}$ : percent of upperclassmen live on campus $\neq$ percent of upperclassmen live off campus

The null hypothesis is rejected concluding there is a difference in percent of upperclassmen living on campus and upperclassmen living off campus.

Table 22. Current resident breakdown of upperclassmen students.

\begin{tabular}{|c|c|c|c|c|}
\hline $\begin{array}{l}\text { Current } \\
\text { Resident }\end{array}$ & $\begin{array}{l}\text { Percentage of } \\
\text { Upperclassmen }\end{array}$ & $\begin{array}{l}\text { Percentage of } \\
\text { Underclassmen }\end{array}$ & $\begin{array}{l}\text { Number of } \\
\text { Respondents }\end{array}$ & P-Value \\
\hline On Campus & $45 \%$ & $55 \%$ & 33 & \multirow[t]{2}{*}{$0.00^{\star \star}$} \\
\hline Off Campus & $89 \%$ & $11 \%$ & 47 & \\
\hline
\end{tabular}

Table 23 indicates the college major breakdown of respondents who are upperclassmen. Of the animal science majors 69 percent are upperclassmen while $100 \%$ of dairy science majors are upperclassmen.

$\mathrm{H}_{0}$ : percent of upperclassmen animal science major $=$ percent of upperclassmen dairy science major

$\mathrm{H}_{a}$ : percent of upperclassmen animal science major $\neq$ percent of upperclassmen dairy science major

The null hypothesis fails to be rejected concluding no difference in percent of upperclassmen animal science major and upperclassmen dairy science major. 
Table 23. College major breakdown of upperclassmen students.

\begin{tabular}{|c|c|c|c|c|}
\hline $\begin{array}{l}\text { College } \\
\text { Major }\end{array}$ & $\begin{array}{l}\text { Percentage of } \\
\text { Upperclassmen }\end{array}$ & $\begin{array}{l}\text { Percentage of } \\
\text { Underclassmen }\end{array}$ & $\begin{array}{l}\text { Number of } \\
\text { Respondents }\end{array}$ & P-Value \\
\hline $\begin{array}{l}\text { Animal } \\
\text { Science }\end{array}$ & $69 \%$ & $31 \%$ & 74 & 0.106 \\
\hline $\begin{array}{l}\text { Dairy } \\
\text { Science }\end{array}$ & $100 \%$ & $0 \%$ & 6 & \\
\hline
\end{tabular}

As shown in Table 24, 86 percent of upperclassmen have or are currently taking Animal Science 229 course- Anatomy and Physiology of Farm Animals. Fifty- one percent of upperclassmen undergraduate students indicate they have or a currently taking Animal Science 438 course- Systemic Animal Physiology. This makes sense because ASCI 438 is an upper division course typically only taken by juniors, seniors, or graduate students. Five percent of upperclassmen respondents reported to be student lab managers. Figure 5 displays the breakdown of academic standings and the courses respondents have taken or are currently taking at the CPVC.

$H_{0}$ : percent of upperclassmen student involvement = percent of underclassmen student involvement

$\mathrm{H}_{\mathrm{a}}$ : percent of upperclassmen student involvement $\neq$ percent of underclassmen student involvement

For students taking $\mathrm{ASCl} 227, \mathrm{ASCl} 229$, and $\mathrm{ASCl} 438$, the null hypothesis is rejected concluding there is a difference in percent of 
upperclassmen and percent of underclassmen when examining involvement at the CPVC.

Table 24. Involvement of upperclassmen students.

\begin{tabular}{|c|c|c|c|c|}
\hline Involvement & $\begin{array}{l}\text { Percentage of } \\
\text { Upperclassmen }\end{array}$ & $\begin{array}{l}\text { Percentage of } \\
\text { Underclassmen }\end{array}$ & $\begin{array}{l}\text { Number of } \\
\text { Respondents }\end{array}$ & $\begin{array}{l}\text { P- } \\
\text { Value }\end{array}$ \\
\hline ASCI 290 & $28 \%$ & $35 \%$ & 24 & 0.553 \\
\hline ASCl 227 & $44 \%$ & $70 \%$ & 41 & $0.037^{\star \star}$ \\
\hline ASCI 310 & $37 \%$ & $26 \%$ & 27 & 0.357 \\
\hline ASCl 229 & $86 \%$ & $35 \%$ & 57 & $0.00^{\star \star}$ \\
\hline ASCI 438 & $51 \%$ & $0 \%$ & 29 & $0.00^{\star \star}$ \\
\hline $\begin{array}{l}\text { Student Lab } \\
\text { Teacher }\end{array}$ & $5 \%$ & $0 \%$ & 3 & 0.262 \\
\hline Volunteer & $5 \%$ & $9 \%$ & 5 & 0.566 \\
\hline
\end{tabular}




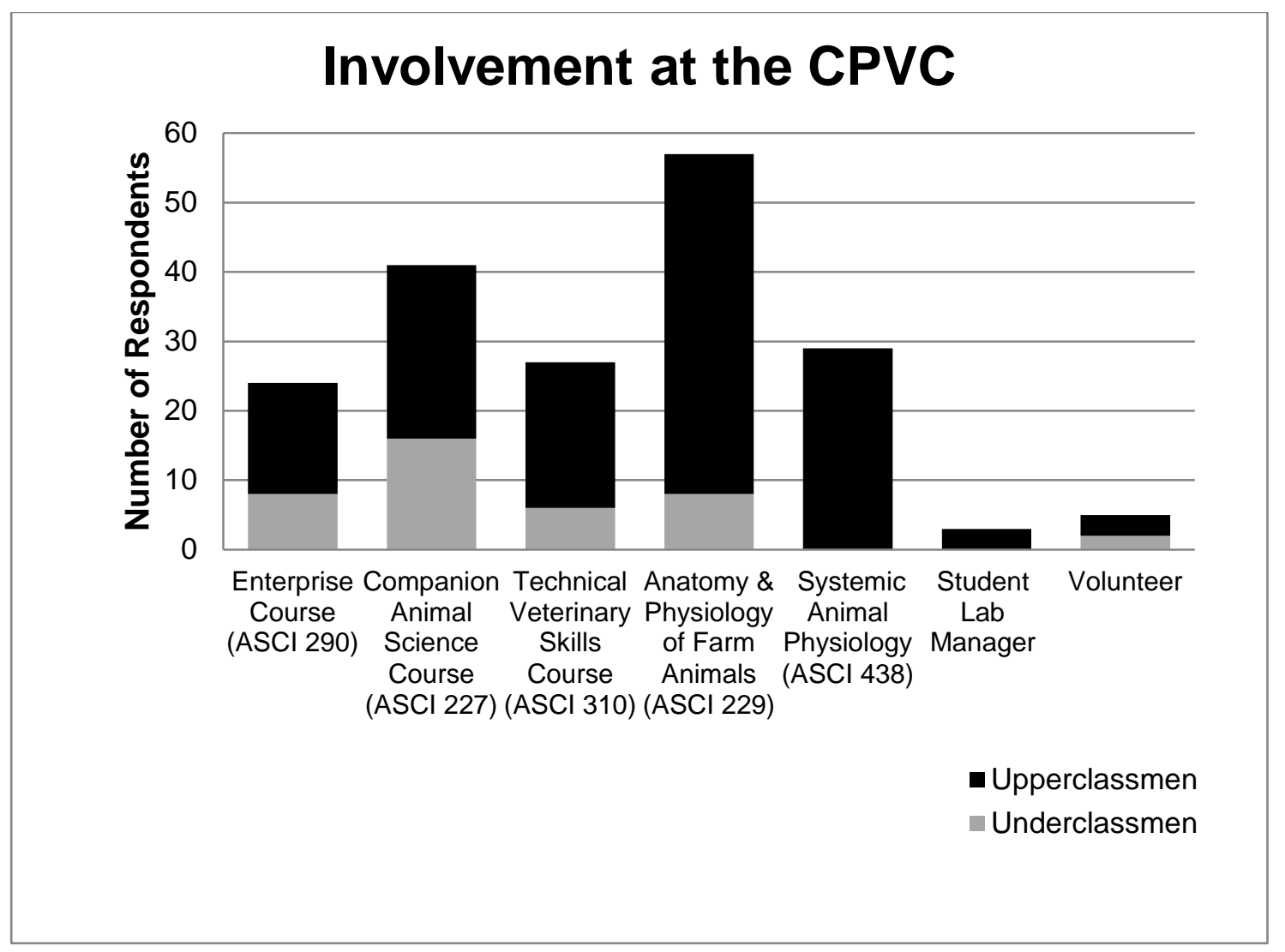

Figure 5. Upperclassmen breakdown of student involvement at the CPVC.

Table 25 shows the number of hours spent at the CPVC of upperclassmen students. Of the upperclassmen, seventy- one percent spend 2.1 to 4 hours per week at the CPVC.

$H_{0}$ : percent of hours spent by upperclassmen students= percent of hours spent by underclassmen students

$H_{a}$ : percent of hours spent by upperclassmen students $\neq$ percent of hours spent by underclassmen students 
The null hypothesis fails to be rejected concluding no difference in percent of upperclassmen and percent of underclassmen when examining average time spent at the CPVC.

Table 25. Hours spent at the CPVC by upperclassmen students.

\begin{tabular}{|c|c|c|c|c|}
\hline Hours & $\begin{array}{l}\text { Percentage of } \\
\text { Upperclassmen }\end{array}$ & $\begin{array}{l}\text { Percentage of } \\
\text { Underclassmen }\end{array}$ & $\begin{array}{l}\text { Number of } \\
\text { Respondents }\end{array}$ & P-Value \\
\hline $0-2.0 \mathrm{hrs}$ & $5 \%$ & $9 \%$ & 5 & 0.722 \\
\hline $2.1-4.0 \mathrm{hrs}$ & $71 \%$ & $78 \%$ & 58 & \\
\hline $4.1-6.0 \mathrm{hrs}$ & $14 \%$ & $9 \%$ & 12 & \\
\hline $6.1-8.0 \mathrm{hrs}$ & $2 \%$ & $0 \%$ & 1 & \\
\hline $8.1-10.0$ hrs & $2 \%$ & $4 \%$ & 1 & \\
\hline $10.1+$ hours & $5 \%$ & $0 \%$ & 3 & \\
\hline
\end{tabular}

Table 26 breaks down the number of quarters upperclassmen students have spent at the CPVC, including the current Spring 2014 quarter. Of the Upperclassmen students, 40 percent have been involved at the CPVC for an average of two quarters.

$\mathrm{H}_{0}$ : percent of quarters spent by upperclassmen students= percent of quarters spent by underclassmen students

$\mathrm{H}_{\mathrm{a}}$ : percent of quarters spent by upperclassmen students $\neq$ percent of quarters spent by underclassmen students 
The null hypothesis is rejected concluding there is a difference in percent of upperclassmen and percent of underclassmen when examining number of quarters spent at the CPVC.

Table 26. Number of quarters spent at the CPVC by upperclassmen students.

\begin{tabular}{|c|c|c|c|c|}
\hline Quarters & $\begin{array}{l}\text { Percentage of } \\
\text { Upperclassmen }\end{array}$ & $\begin{array}{l}\text { Percentage of } \\
\text { Underclassmen }\end{array}$ & $\begin{array}{l}\text { Number of } \\
\text { Respondents }\end{array}$ & P-Value \\
\hline 1 & $12 \%$ & $35 \%$ & 15 & \multirow{5}{*}{$0.015^{\star \star}$} \\
\hline 2 & $40 \%$ & $57 \%$ & 36 & \\
\hline 3 & $36 \%$ & $4 \%$ & 19 & \\
\hline 4 & $2 \%$ & $0 \%$ & 1 & \\
\hline $5+$ & $14 \%$ & $4 \%$ & 9 & \\
\hline
\end{tabular}

According to the results and shown in Table 27, 65 percent of upperclassmen students plan on attending veterinary medical school after graduation from Cal Poly.

$\mathrm{H}_{0}$ : percent of upperclassmen veterinary medical school= percent of upperclassmen master graduate program = percent of upperclassmen doctoral program = percent of upperclassmen RVT= percent of upperclassmen no plans

$\mathrm{H}_{\mathrm{a}}$ : percent of upperclassmen veterinary medical school\# percent of upperclassmen master graduate program $\neq$ percent of upperclassmen doctoral program $\neq$ percent of upperclassmen RVT $\neq$ percent of upperclassmen no plans 
The null hypothesis fails to be rejected concluding no difference in percent of upperclassmen when comparing programs students plan on attending after graduation.

Table 27. Programs upperclassmen students plan on attending after graduation.

\begin{tabular}{|c|c|c|c|}
\hline Programs & $\begin{array}{l}\text { Percentage of } \\
\text { Upperclassmen }\end{array}$ & $\begin{array}{l}\text { Percentage of } \\
\text { Underclassmen }\end{array}$ & $\begin{array}{l}\text { Number of } \\
\text { Respondents }\end{array}$ \\
\hline $\begin{array}{l}\text { Veterinary } \\
\text { Medical } \\
\text { School }\end{array}$ & $65 \%$ & $65 \%$ & 52 \\
\hline $\begin{array}{l}\text { Master } \\
\text { Graduate } \\
\text { Program }\end{array}$ & $15 \%$ & $17 \%$ & 13 \\
\hline $\begin{array}{l}\text { Doctoral } \\
\text { Program } \\
\text { (other than } \\
\text { vet school) }\end{array}$ & $4 \%$ & $0 \%$ & 2 \\
\hline $\begin{array}{l}\text { Registered } \\
\text { Veterinary } \\
\text { Technician }\end{array}$ & $4 \%$ & $9 \%$ & 4 \\
\hline $\begin{array}{l}\text { Not planning } \\
\text { on attending } \\
\text { any program }\end{array}$ & $12 \%$ & $9 \%$ & 9 \\
\hline
\end{tabular}

Important benefits of the CPVC

The following results analyze Question 17 that addresses the respondents' opinion on importance of various benefits when participating at the CPVC.

The different benefits were categorized into three groups; Table 28 presents the different categories for each benefit. Chi- square tests for independence of two variables were conducted on this categorical data to determine relationships among the pre-vet students or academic class standings and Question 17. 
Table 28. Categories of benefits of the CPVC.

\begin{tabular}{|c|c|c|}
\hline $\begin{array}{l}\text { Veterinary Skill } \\
\text { Development }\end{array}$ & $\begin{array}{l}\text { Veterinary Career } \\
\text { Preparation }\end{array}$ & Facility Staff \\
\hline $\begin{array}{l}\text { - Hands-on Learning } \\
\text { - Practical Animal } \\
\text { Exposure } \\
\text { - Veterinary } \\
\text { Technician Skill } \\
\text { Development }\end{array}$ & $\begin{array}{ll}\text { - } & \text { Resume building } \\
\text { - } & \text { Preparation for } \\
\text { Veterinary Medical } \\
\text { School } \\
\text { - }\end{array}$ & $\begin{array}{ll}\text { - } & \text { Veterinarians } \\
\text { - } & \text { Student Managers }\end{array}$ \\
\hline
\end{tabular}

The academic class standings of respondents were grouped into three groups. The first group consisted of freshmen and sophomores. The second group was just juniors, and the third group combined seniors and graduate students. The Likert Scale was also adjusted to combine slightly important, somewhat important, and not important at all into one group resulting in three different rating options; extremely important, very important, slightly to not important at all.

The majority of respondents (62 percent) reported veterinary skill development is an extremely important benefit of the CPVC while 44 percent of respondents reported that facility staff is an extremely important part of the CPVC. Table 29 illustrates the important benefit breakdown of survey respondents. 
Table 29. Respondent breakdown of extremely important benefits of the CPVC.

\begin{tabular}{|c|c|c|}
\hline Extremely Important & Number of Respondents & $\begin{array}{l}\text { Percent of Total } \\
\text { ( } N=237)\end{array}$ \\
\hline $\begin{array}{l}\text { Veterinary Skill } \\
\text { Development }\end{array}$ & 146 & $62 \%$ \\
\hline $\begin{array}{l}\text { Veterinary Career } \\
\text { Preparation }\end{array}$ & 103 & $44 \%$ \\
\hline Facility Staff & 69 & $44 \%$ \\
\hline
\end{tabular}

When analyzing respondents who are pre-vet undergraduate students the null hypothesis is pre-vet and non -pre-vet students rate the same in level of importance of veterinary skill development. The alternative hypothesis is there is a difference between pre-vet and non-pre-vet students in their level of importance of veterinary skill development. Sixty-nine percent of pre-vet respondents rated veterinary skill development to be an extremely important benefit of the CPVC. Table 30 shows the rating of veterinary skill development benefit breakdown of respondents who are pre-vet students.

Table 30. Veterinary Skill Development rating scale of importance breakdown of pre-vet undergraduate students.

\begin{tabular}{|l|l|l|l|}
\hline $\begin{array}{l}\text { Veterinary SkIll } \\
\text { Development }\end{array}$ & $\begin{array}{l}\text { Percentage of } \\
\text { Pre-Vet Students }\end{array}$ & $\begin{array}{l}\text { Percentage of } \\
\text { Non-Pre-Vet } \\
\text { Students }\end{array}$ & $\begin{array}{l}\text { Percent Total } \\
\text { (N=237) }\end{array}$ \\
\hline $\begin{array}{l}\text { Extremely } \\
\text { Important }\end{array}$ & $69 \%$ & $46 \%$ & $62 \%$ \\
\hline Very Important & $27 \%$ & $37 \%$ & $30 \%$ \\
\hline $\begin{array}{l}\text { Slightly to Not } \\
\text { Important at all }\end{array}$ & $4 \%$ & $17 \%$ & $8 \%$ \\
\hline
\end{tabular}

Table 31 indicates the rating of veterinary career preparation benefit breakdown of the respondents who are pre-vet students. The null hypothesis is 
pre-vet and non-pre-vet students rate the same in level of importance of veterinary career preparation. The alternative hypothesis is there is a difference between pre-vet and non-pre-vet students in their level of importance of veterinary career preparation. Forty- nine percent of pre-vet respondents rated this benefit to be extremely important to CPVC.

Table 31. Veterinary Career Preparation rating scale of importance breakdown of pre-vet undergraduate students

\begin{tabular}{|l|l|l|l|}
$\begin{array}{l}\text { Veterinary Career } \\
\text { Preparation }\end{array}$ & $\begin{array}{l}\text { Percentage of } \\
\text { Pre-Vet Students }\end{array}$ & $\begin{array}{l}\text { Percentage of } \\
\text { Non-Pre-Vet } \\
\text { Students }\end{array}$ & $\begin{array}{l}\text { Percent Total } \\
\text { (N=237) }\end{array}$ \\
\hline $\begin{array}{l}\text { Extremely } \\
\text { Important }\end{array}$ & $49 \%$ & $32 \%$ & $44 \%$ \\
\hline Very Important & $34 \%$ & $44 \%$ & $37 \%$ \\
\hline $\begin{array}{l}\text { Slightly to Not } \\
\text { Important At All }\end{array}$ & $17 \%$ & $24 \%$ & $19 \%$ \\
\hline
\end{tabular}

Table 32 illustrates the rating of facility staff benefit breakdown of the respondents who are pre- vet students. The null hypothesis is pre-vet and non pre-vet students rate the same in level of importance of facility staff. The alternative hypothesis is there is a difference between pre-vet and non-pre-vet students in their level of importance of facility staff. The table shows 51 percent of pre-vet students rated facility staff to be extremely important to the CPVC. 
Table 32. Facility Staff rating scale of importance breakdown of pre-vet undergraduate students.

\begin{tabular}{|l|l|l|l|}
\hline Facility Staff & $\begin{array}{l}\text { Percentage of } \\
\text { Pre-Vet Students }\end{array}$ & $\begin{array}{l}\text { Percentage of } \\
\text { Non-Pre-Vet } \\
\text { Students }\end{array}$ & $\begin{array}{l}\text { Percent Total } \\
\text { (N=237) }\end{array}$ \\
\hline $\begin{array}{l}\text { Extremely } \\
\text { Important }\end{array}$ & $51 \%$ & $29 \%$ & $44 \%$ \\
\hline Very Important & $37 \%$ & $56 \%$ & $43 \%$ \\
\hline $\begin{array}{l}\text { Slightly to Not } \\
\text { Important At All }\end{array}$ & $12 \%$ & $15 \%$ & $13 \%$ \\
\hline
\end{tabular}

When analyzing different academic levels of students, the null hypothesis is academic standing is independent of the importance of veterinary skill development. The alternative hypothesis is academic standing is dependent of the importance of veterinary skill development. Results for different levels of academic standings at Cal Poly indicate that 71 percent of seniors and graduate students reported veterinary skill development to be an extremely important benefit of the CPVC. Table 33 shows the breakdown of academic standing and rating of this benefit.

Table 33. Veterinary Skill Development rating scale of importance breakdown of academic class standings for Cal Poly students.

\begin{tabular}{|l|l|l|l|l|}
\hline $\begin{array}{l}\text { Veterinary Skill } \\
\text { Development }\end{array}$ & $\begin{array}{l}\text { Freshmen/ } \\
\text { Sophomores }\end{array}$ & Juniors & \multicolumn{1}{|l|}{$\begin{array}{l}\text { Seniors/ } \\
\text { Graduate } \\
\text { Students }\end{array}$} & $\begin{array}{l}\text { Percent } \\
\text { Total } \\
\text { (N=237) }\end{array}$ \\
\hline $\begin{array}{l}\text { Extremely } \\
\text { Important }\end{array}$ & $58 \%$ & $55 \%$ & $71 \%$ & $62 \%$ \\
\hline Very Important & $32 \%$ & $35 \%$ & $25 \%$ & $30 \%$ \\
\hline $\begin{array}{l}\text { Slightly to Not } \\
\text { Important At All }\end{array}$ & $10 \%$ & $10 \%$ & $4 \%$ & $8 \%$ \\
\hline
\end{tabular}


Table 34 demonstrates the rating scale of different academic levels of respondents with regards to veterinary career preparation. The null hypothesis for this data is academic standing is independent of the importance of veterinary career preparation. The alternative hypothesis is academic standing is dependent of the importance of veterinary career preparation. Fifty- one percent of seniors and graduate students reported veterinary career preparation to be an extremely important benefit of the CPVC. This is compared to 36 percent of juniors and 42 percent of freshmen and sophomores.

Table 34. Veterinary Career Preparation rating scale of importance breakdown of academic class standings for Cal Poly students.

\begin{tabular}{|c|c|c|c|c|}
\hline $\begin{array}{l}\text { Veterinary } \\
\text { Career } \\
\text { Preparation }\end{array}$ & $\begin{array}{l}\text { Freshmen/ } \\
\text { Sophomores }\end{array}$ & Juniors & $\begin{array}{l}\text { Seniors/ } \\
\text { Graduate } \\
\text { Students }\end{array}$ & $\begin{array}{l}\text { Percent } \\
\text { Total } \\
(\mathrm{N}=237)\end{array}$ \\
\hline $\begin{array}{l}\text { Extremely } \\
\text { Important }\end{array}$ & $44 \%$ & $36 \%$ & $51 \%$ & $44 \%$ \\
\hline Very Important & $42 \%$ & $36 \%$ & $35 \%$ & $37 \%$ \\
\hline $\begin{array}{l}\text { Slightly to Not } \\
\text { Important At All }\end{array}$ & $14 \%$ & $28 \%$ & $14 \%$ & $18 \%$ \\
\hline
\end{tabular}

When comparing academic standing and facility staff, the null hypothesis is academic standing is independent of the importance of facility staff. The alternative hypothesis is academic standing is dependent of the importance of facility staff. Table 35 shows 52 percent of seniors and graduate students rated the facility staff to be an extremely important benefit of the CPVC. Thirty- six percent of freshmen and sophomore respondents reported the facility staff to be an extremely important benefit of the CPVC. 
Table 35. Facility Staff rating scale of importance breakdown of academic class standings for Cal Poly students.

\begin{tabular}{l|l|l|l|l|}
\hline Facility Staff & \multicolumn{2}{l}{$\begin{array}{l}\text { Freshmen/ Juniors } \\
\text { Sophomores }\end{array}$} & \multicolumn{3}{|l|}{$\begin{array}{l}\text { Seniors/ } \\
\text { Graduate } \\
\text { Students }\end{array}$} & $\begin{array}{l}\text { Percent } \\
\text { Total } \\
\text { (N=237) }\end{array}$ \\
\hline $\begin{array}{l}\text { Extremely } \\
\text { Important }\end{array}$ & $36 \%$ & $41 \%$ & $52 \%$ & $44 \%$ \\
\hline Very Important & $55 \%$ & $41 \%$ & $36 \%$ & $43 \%$ \\
\hline $\begin{array}{l}\text { Slightly to Not } \\
\text { Important At } \\
\text { All }\end{array}$ & $9 \%$ & $18 \%$ & $12 \%$ & $13 \%$ \\
\hline
\end{tabular}

Table 36 indicates that at a significance level of 5 percent and a critical value of 7.81 , pre-vet students who rate the benefits of importance is associated with the facility staff and veterinary skill development. Therefore, the null hypothesis is rejected when comparing pre-vet and non-pre-vet students of having the same level of importance when examining facility staff and veterinary skill development. Table 36 also indicates that at a significance level of 5 percent and a critical value of 9.49 , academic standing is dependent on veterinary career preparation. And in this case this null hypothesis is rejected.

Table 36. Chi-squared test statistic value for important benefits of the CPVC.

\begin{tabular}{|l|l|l|}
$\begin{array}{l}\text { Extremely } \\
\text { Satisfied }\end{array}$ & $\begin{array}{l}\text { Pre-vet } \\
\text { Undergraduate } \\
\text { Students }\end{array}$ & $\begin{array}{l}\text { Academic Class } \\
\text { Standings }\end{array}$ \\
\hline $\begin{array}{l}\text { Veterinary Skill } \\
\text { Development }\end{array}$ & $\mathbf{1 8 . 8 3}^{\star \star}$ & 6.54 \\
\hline $\begin{array}{l}\text { Veterinary Career } \\
\text { Preparation }\end{array}$ & 6.54 & $\mathbf{1 0 . 9 3}^{\star \star}$ \\
\hline Facility Staff & $\mathbf{1 2 . 1 5}^{\star \star}$ & 5.05 \\
\hline
\end{tabular}


Satisfied factors of the CPVC

The following results analyze Question 18 that addresses the respondents' opinion on level of satisfaction of various factors when participating at the CPVC.

The different various factors were categorized into three groups, Table 28 presents the different categories for each factor. Chi- square tests for independence of two variables were conducted on this categorical data to determine relationships among pre-vet student or different academic class standings and Question 18.

The academic class standing was grouped into three groups. The first group consisted of freshmen and sophomores. The second group was just juniors, and the third group combined seniors and graduate students. The Likert Scale was also adjusted to combine slightly satisfied, somewhat satisfied, and not satisfied at all into one group resulting in three different rating options. The Likert Scale is extremely satisfied, very satisfied, slightly to not satisfied at all.

Forty-two percent of respondents reported they are extremely satisfied with the level of veterinary skill development seen at the CPVC while 45 percent of respondents reported to be extremely satisfied with the facility staff at the CPVC. Table 37 illustrates the important benefit breakdown of survey respondents. 
Table 37. Respondent breakdown of extremely satisfied factors of the CPVC

\begin{tabular}{|l|l|l|}
\hline Extremely Satisfied & Number of Respondents & $\begin{array}{l}\text { Percent of Total } \\
(\mathbf{N}=237)\end{array}$ \\
\hline $\begin{array}{l}\text { Veterinary Skill } \\
\text { Development }\end{array}$ & 99 & $42 \%$ \\
\hline $\begin{array}{l}\text { Veterinary Career } \\
\text { Preparation }\end{array}$ & 72 & $30 \%$ \\
\hline Facility Staff & 71 & $45 \%$ \\
\hline
\end{tabular}

When analyzing respondents who are pre-vet undergraduate the null hypothesis is pre-vet and non -pre-vet students have the same level of satisfaction of veterinary skill development at the CPVC. The alternative hypothesis is there is a difference between pre-vet and non-pre-vet students in their level of satisfaction of veterinary skill development. Forty-two percent of respondents rated extremely satisfied with veterinary skill development at the CPVC. Table 38 shows the rating of veterinary skill development factor breakdown of respondents who are pre-vet undergraduate students.

Table 38. Veterinary Skill Development rating scale of satisfaction level breakdown of pre-vet undergraduate students.

\begin{tabular}{|l|l|l|l|}
\hline $\begin{array}{l}\text { Veterinary Skill } \\
\text { Development }\end{array}$ & $\begin{array}{l}\text { Percentage of } \\
\text { Pre-Vet Students }\end{array}$ & $\begin{array}{l}\text { Percentage of } \\
\text { Non-Pre-Vet } \\
\text { Students }\end{array}$ & $\begin{array}{l}\text { Percent Total } \\
\text { (N=237) }\end{array}$ \\
\hline $\begin{array}{l}\text { Extremely } \\
\text { Satisfied }\end{array}$ & $42 \%$ & $41 \%$ & $41 \%$ \\
\hline Very Satisfied & $38 \%$ & $45 \%$ & $41 \%$ \\
\hline $\begin{array}{l}\text { Slightly to Not } \\
\text { Satisfied At All }\end{array}$ & $20 \%$ & $14 \%$ & $18 \%$ \\
\hline
\end{tabular}

Table 39 indicates respondents who are pre-vet students' satisfaction of the veterinary career preparation at the CPVC. The null hypothesis is pre-vet and 
non -pre-vet students have the same in level of satisfaction of veterinary career preparation. The alternative hypothesis is there is a difference between pre-vet and non-pre-vet students in their level of satisfaction of veterinary career preparation Thirty- one percent of respondents are extremely satisfied with the CPVC veterinary career preparation.

Table 39. Veterinary Career Preparation rating scale of satisfaction level breakdown of pre-vet undergraduate students.

\begin{tabular}{|l|l|l|l|}
$\begin{array}{l}\text { Veterinary Career } \\
\text { Preparation }\end{array}$ & $\begin{array}{l}\text { Percentage of } \\
\text { Pre-Vet Students }\end{array}$ & $\begin{array}{l}\text { Percentage of } \\
\text { Non-Pre-Vet } \\
\text { Students }\end{array}$ & $\begin{array}{l}\text { Percent Total } \\
\text { (N=237) }\end{array}$ \\
\hline $\begin{array}{l}\text { Extremely } \\
\text { Satisfied }\end{array}$ & $30 \%$ & $30 \%$ & $30 \%$ \\
\hline Very Satisfied & $41 \%$ & $43 \%$ & $42 \%$ \\
\hline $\begin{array}{l}\text { Slightly to Not } \\
\text { Satisfied At All }\end{array}$ & $29 \%$ & $27 \%$ & $28 \%$ \\
\hline
\end{tabular}

Table 40 illustrates respondents who are pre-vet undergraduate students' satisfaction of the facility staff at the CPVC. The null hypothesis is pre-vet and non -pre-vet students have the same level of satisfaction of facility staff. The alternative hypothesis is there is a difference between pre-vet and non-pre-vet students in their level of satisfaction of facility staff. The table shows that 47 percent of pre-vet undergraduate students are extremely satisfied with facility staff at the CPVC. 
Table 40. Facility Staff rating scale of satisfaction level breakdown of pre-vet undergraduate students.

\begin{tabular}{|l|l|l|l|}
\hline Facility Staff & $\begin{array}{l}\text { Percentage of } \\
\text { Pre-Vet Students }\end{array}$ & $\begin{array}{l}\text { Percentage of } \\
\text { Non-Pre-Vet } \\
\text { Students }\end{array}$ & $\begin{array}{l}\text { Percent Total } \\
\text { (N=237) }\end{array}$ \\
\hline Extremely Satisfied & $47 \%$ & $42 \%$ & $45 \%$ \\
\hline Very Satisfied & $30 \%$ & $41 \%$ & $34 \%$ \\
\hline $\begin{array}{l}\text { Slightly to Not } \\
\text { Satisfied At All }\end{array}$ & $23 \%$ & $17 \%$ & $21 \%$ \\
\hline
\end{tabular}

When analyzing different academic levels of students, the null hypothesis is academic standing is independent of the level of satisfaction of veterinary skill development. The alternative hypothesis is academic standing is dependent of the level of satisfaction of veterinary skill development. Results for different levels of academic standings at Cal Poly indicate 45 percent of seniors and graduate students reported to be extremely satisfied with the veterinary skill development at the CPVC. Table 41 shows the breakdown of academic standing and rating of this benefit.

Table 41. Veterinary Skill Development rating scale of satisfaction level breakdown of academic class standings for Cal Poly students.

\begin{tabular}{|c|c|c|c|c|}
\hline $\begin{array}{l}\text { Veterinary Skill } \\
\text { Development }\end{array}$ & $\begin{array}{l}\text { Freshmen/ } \\
\text { Sophomores }\end{array}$ & Juniors & $\begin{array}{l}\text { Seniors/ } \\
\text { Graduate } \\
\text { Students }\end{array}$ & $\begin{array}{l}\text { Percent } \\
\text { Total } \\
(\mathrm{N}=237)\end{array}$ \\
\hline $\begin{array}{l}\text { Extremely } \\
\text { Satisfied }\end{array}$ & $39 \%$ & $41 \%$ & $45 \%$ & $41 \%$ \\
\hline Very Satisfied & $47 \%$ & $39 \%$ & $37 \%$ & $41 \%$ \\
\hline $\begin{array}{l}\text { Slightly to Not } \\
\text { Satisfied At All }\end{array}$ & $14 \%$ & $20 \%$ & $18 \%$ & $18 \%$ \\
\hline
\end{tabular}


Table 42 demonstrates the rating scale of different academic levels of respondents with regards to veterinary career preparation. The null hypothesis for this data is academic standing is independent of the level of satisfaction of veterinary career preparation. The alternative hypothesis is academic standing is dependent of the level of satisfaction of veterinary career preparation. Thirtythree percent of seniors and graduate students reported extremely satisfied with the veterinary career preparation at the CPVC. This is compared to 29 percent of freshmen, sophomores, and juniors.

Table 42. Veterinary Career Preparation rating scale of satisfaction level breakdown of academic class standings for Cal Poly students.

\begin{tabular}{|l|l|l|l|l|}
\hline $\begin{array}{l}\text { Veterinary } \\
\text { Career } \\
\text { Preparation }\end{array}$ & \multicolumn{1}{|l|}{$\begin{array}{l}\text { Freshmen/ } \\
\text { Sophomores }\end{array}$} & Juniors & \multicolumn{2}{|l|}{$\begin{array}{l}\text { Seniors/ } \\
\text { Graduate } \\
\text { Students }\end{array}$} \\
\hline $\begin{array}{l}\text { Extremely } \\
\text { Satisfied }\end{array}$ & $29 \%$ & $29 \%$ & $33 \%$ & $\begin{array}{l}\text { Percent } \\
\text { Total } \\
\text { (N=237) }\end{array}$ \\
\hline Very Satisfied & $47 \%$ & $39 \%$ & $39 \%$ & $42 \%$ \\
\hline $\begin{array}{l}\text { Slightly to Not } \\
\text { Satisfied At All }\end{array}$ & $24 \%$ & $32 \%$ & $28 \%$ & $28 \%$ \\
\hline
\end{tabular}

When comparing academic standing and facility staff, the null hypothesis is academic standing is independent of the level of satisfaction of facility staff. The alternative hypothesis is academic standing is dependent of the level of satisfaction of facility staff. The survey results in Table 43 shows 47 percent of seniors and graduate students are extremely satisfied with the facility staff at the CPVC. Forty- four percent of freshmen and sophomore respondents reported to be extremely satisfied with the facility staff at the CPVC as well. 
Table 43. Facility Staff rating scale of satisfaction level breakdown of academic class standings for Cal Poly students.

\begin{tabular}{|l|l|l|l|l|}
\hline Facility Staff & \multicolumn{2}{|c|}{$\begin{array}{l}\text { Freshmen/ } \\
\text { Sophomores }\end{array}$} & Juniors & \multicolumn{2}{|c|}{$\begin{array}{l}\text { Seniors/ } \\
\text { Graduate } \\
\text { Students }\end{array}$} & $\begin{array}{l}\text { Percent } \\
\text { Total } \\
\text { (N=237) }\end{array}$ \\
\hline $\begin{array}{l}\text { Extremely } \\
\text { Satisfied }\end{array}$ & $44 \%$ & $45 \%$ & $47 \%$ & $45 \%$ \\
\hline Very Satisfied & $42 \%$ & $34 \%$ & $28 \%$ & $34 \%$ \\
\hline $\begin{array}{l}\text { Slightly to Not } \\
\text { Satisfied At All }\end{array}$ & $14 \%$ & $21 \%$ & $25 \%$ & $21 \%$ \\
\hline
\end{tabular}

Table 44 indicates that at a significance level of 5 percent and a critical value of 7.81 , pre-vet undergraduate students who rates the level of satisfaction at the CPVC is not associated with the facility staff, veterinary skill development, or the veterinary career preparation factors. Therefore, the null hypothesis fails to be rejected when comparing pre-vet undergraduate students and non-pre-vet undergraduate of having the same satisfaction level when examining facility staff, veterinary skill development, and veterinary career preparation. Table 36 also indicates that at a significance level of 5 percent and a critical value of 9.49 , academic standing is independent of veterinary career preparation, veterinary skill development, and facility staff. And in this case the null hypothesis fails to be rejected. 
Table 44. Chi-squared test statistic value for satisfaction levels of factors at the CPVC

\begin{tabular}{|l|l|l|}
\hline Extremely Satisfied & $\begin{array}{l}\text { Pre-vet } \\
\text { Undergraduate } \\
\text { Students }\end{array}$ & $\begin{array}{l}\text { Academic Class } \\
\text { Standings }\end{array}$ \\
\hline $\begin{array}{l}\text { Veterinary Skill } \\
\text { Development }\end{array}$ & 1.42 & 2.27 \\
\hline $\begin{array}{l}\text { Veterinary Career } \\
\text { Preparation }\end{array}$ & 0.11 & 1.93 \\
\hline Facility Staff & 1.67 & 3.20 \\
\hline
\end{tabular}




\section{CHAPTER 5}

Summary

The purpose of the study was to research and determine the important benefits of the CPVC and establish areas of interest for students. Research was formulated prior to the survey to provide existing knowledge of learning environments of university level agricultural students. A survey was developed and administered to over three hundred Cal Poly students who have or are currently taking any of the five courses offered at the CPVC. The results of eighty respondents were analyzed to test the study's hypothesis and complete the objectives of the study.

The overall hypothesis stated that the Cal Poly Veterinary Clinic is an important aspect of Cal Poly's Animal Science Department and students participating at the CPVC are satisfied with a variety of components of the facility. The hypothesis fails to be rejected because several significant associations were determined in each category of questions.

The study had six objectives. The first objective was to collect data on the CPVC from Cal Poly students. The respondents included undergraduate and graduate students who previously took or are currently taking any one of the five courses taught at the CPVC. From this first objective, four more specific objectives were identified. The first was to prioritize the importance of certain benefits offered to students at the CPVC. The benefits include veterinary skill development, veterinary career preparation, and the facility staff. The second objective was to identity students' areas of interest in the field of veterinary 
medicine. These interests included ten possible clinical experiences students could have the opportunity to participate in at the CPVC. The third objective was to identify students' species of interest in the field of veterinary medicine. Again, these interests included eleven species students could have the opportunity to work with while at the CPVC. The forth objective was to prioritize areas of improvements to better satisfy the students participating at the CPVC. Students were questioned on six areas of possible improvements for the veterinary clinic.

From the first objective and four specific objectives, one last objective was established. The sixth objective was to develop a mission statement that reflects the needs and expectations of the students participating at the CPVC as well as the Cal Poly community.

A series of statistical research was conducted that gave knowledge of students participating at the CPVC. This information was used to draw conclusions and make recommendations for the CPVC. For questions on the survey that related to demographics, the majority of the respondents are female (93 percent), living off the Cal Poly campus (59 percent), are animal science majors (93 percent), and come from families that are not involved in agriculture (91 percent). These results are similar to previous research of demographics and agriculture background among college students earning a degree in the college of agriculture.

The data shows 35 percent of respondents were juniors at Cal Poly who owned or family owned a pet (96 percent) and pays for college by financial aid 
(51 percent) or family/ private funds (53 percent). The data also shows 65 percent of respondents plan on attending veterinary medical school after graduation from Cal Poly. While it seems to be a rather low number for students who participate at the CPVC, it can be expected because this facility is not limited to students solely bound for veterinary medical school after graduation. Students in the animal science department have graduation requirements, just like most departments, and some of the required courses take place at the CPVC. For this reason, students participating at the CPVC are not limited to preveterinary undergraduate students. When looking at pre-veterinary status, 66 percent of respondents indicated to be pre-veterinary students. Once again proving, not all students who participate at the CPVC are veterinary medical school bound. This proves that administrators should not tailor courses offered at the CPVC to solely focus on pre-veterinary students, but all students in the field of agriculture.

Overall, the results show that 73 percent of respondents spend two to four hours a week at the CPVC in any given quarter and 45 percent have been involved with the CPVC for two quarters. Seventy-one percent of respondents have or are currently taking Animals Science 229- Anatomy and Physiology of Farm Animals. ASCl 229 is a required course in the animal science major so it is not surprising that over 70 percent of respondents have or are currently taking this course to fulfill graduation requirements.

The students surveyed have a positive association with the CPVC meeting the students' expectations. Many respondents reported that the CPCV offers a lot 
of opportunities for hands- on learning and a variety of practical animal exposure. Respondents also reported that the CPVC building is very old and some of the equipment is out of date, but overall respondents feel that the CPVC is meeting their expectations. These responses coincides with the results of 50 percent of respondents are 'very likely' to recommend the CPVC to other students. As the CPVC meets more of the students' expectations, the more likely students are to recommend the facility to other Cal Poly students.

The survey data shows the top three clinical experiences students participating at the CPVC would most likely to be involved with is anesthetic surgery, physical examinations, and vaccine administration. In a veterinary clinic setting like the CPCV, it is not surprising for surgery to be at the top of the list for many reasons. First, being it is an experience that is not common to be seen in lecture setting classrooms. Also, many pre-veterinary students looking for experience in the veterinary field do not get to participate in any type of animal surgery when interning at veterinary clinics in the community. The least likely clinical experience to participate in at the CPVC is herd health programs. The reason for this largely agricultural experience to be last on the list is uncertain, but relative when determining which clinical experience should be offered at the CPVC.

In the future, with the possibility of a new veterinary clinic to be built, a surgical viewing room or window would be recommended to allow for students to experience anesthetic surgeries in the field of veterinary medicine without compromising the health of the animal being treated. Animal anesthetic surgery 
is not something that can be experienced in a classroom, and through the CPVC, Cal Poly has the opportunity to have students experience animal surgery on a regular basis.

In the past, the CPVC has hosted spay and neuter days for local dogs and cats in the Cal Poly community. This is another opportunity for the CPVC to involve students through the Cal Poly 'Learn by Doing' motto. By hosting quartering or yearly spay and neuter surgery days, students at the CPVC will be able to, not only experience animal surgery first hand, but also learn about all aspect of anesthetic surgery for animals of all shapes and sizes. Once again, building a greater bond between the Cal Poly University and the San Luis Obispo community as well as offering unique hands-on experience to students.

Furthermore, the data indicates the top three animal species respondents participating at the CPVC are most interested in are small animals, mixed practice, and wild life. Small animals consist of most household pets including dogs, cats, and pocket pets. Mixed practice is a combination of both small and large animals and wildlife animals are a variety of animals that solely live in the wild. These results are very surprising because Cal Poly is a largely based agriculture school with the majority of Cal Poly's animal science department focusing on large agriculture animals in their curriculum. These animals include sheep, goats, beef and dairy cattle. The bottom three species respondents are least interested in are dairy animals, avian, and fish. While 7 percent of the respondents reported to be a dairy science major, dairy cattle are the third to last 
interested species. The reason for this concept is uncertain, but there is obviously a stronger interest in small domesticated animals.

Since Cal Poly is largely known for its focus on agriculture animals and production, it is important for the administration to decide which direction the CPVC will need to take in the future. Cal Poly could continue to focus on agriculture production animals and develop new recruiting strategies to attractive prospective students who are interested in agriculture animals and production. Cal Poly Through the recruitment of student interested in agriculture production animals opposed to companion animal science, the CPVC will be able to continue to focus their efforts on teaching students about agriculture animals.

As previous literature has stated, many animal science departments are revising their curriculum to include a greater focus on companion animals and pre-veterinary medicine. Cal Poly could change their focus to better meet the needs of the students interested in small animal medicine. The CPVC could expand some of the courses curriculum to have a larger focus on small animal medicine. To increase the hands-on student learning at the CPVC in small animal medicine, the clinic could develop a vaccine day for dogs and cats of $\mathrm{Cal}$ Poly students and faculty. By offering a reduced price on vaccines one day a quarter, students participating at the CPVC would have the opportunity to part take in this small animal medicine activity while learning about the proper treatments and techniques of vaccinating a client's animals. 
For small animal treatments, the CPVC is largely dependent on patients being brought in from clients of Cal Poly faculty or community. To increase the focus on small animal medicine at the clinic, the CPVC could update their webpage to include hours of operations and guidelines on what to expect at an appointment. By having the information available to clients, potential new clients will be fully aware of how the CPVC teaching facility works in providing healthcare to clients' pets. By updating the CPVC webpage, the CPVC will be able to advertise its services to Cal Poly faculty, students, and the community of San Luis Obispo

The student respondents were asked to rank eight different benefits of the CPVC in order of importance from extremely important to not important at all. Respondents reported hands-on learning, practical animal exposure, preparation for veterinary medical school, veterinary technician skill development, and the veterinarians to be extremely important benefits of the CPVC. Students value the different aspects this hands-on learning environment has to offer while also understanding the importance of skill building for a future career in veterinary medicine. With the majority of respondents coming from backgrounds with no agricultural experiences it is important to provide students with the desired skill sets to be a successful employee in a career in agriculture, specifically in the field of veterinary medicine. Students understand the importance of learning skills through hands-on practical experiences which will allow them to be successfully employed upon graduation. 
When analyzing pre-veterinary undergraduate students, 51 percent of students rated the facility staff to be an extremely important benefit of the CPVC. This proves that the facility staff is more important to pre-veterinary undergraduate students and matters more to these students than non-preveterinary students.

Furthermore, the data shows that 69 percent of pre-veterinary undergraduate students rated veterinary skill development to be extremely important for the CPVC. The results indicate there is an association between preveterinary undergraduate students and the level of importance of veterinary skill development. Pre-veterinary undergraduate student value the important of learning different veterinary skills like technician skills more so than students who are not pre-veterinary undergraduate students. More than anything, this proves that teaching different veterinary skills should be available to all students, but especially those who have declared to pre-veterinary undergraduate students.

The data indicates there is an association between students of different grade levels and levels of importance of veterinary career preparation at CPVC. Fifty- one percent of seniors and graduate students reported veterinary career preparation to be an extremely important benefit of the CPVC. Students who are seniors and graduate students value the benefit of being prepared for a career in veterinary medicine more so than students who are freshmen, sophomores, or juniors. This proves that as the student progresses in their college career being prepared for a career, in this case, a career in veterinary medicine becomes more important to the student. 
When respondents were asked to rank their satisfaction level of eight different aspects of the CPVC, five of the eights factors were reported at extremely satisfied. These factors included practical animal exposure, preparation for veterinary medical school, veterinary technician skill development, the veterinarians, and the student manager. Previous data also indicated that the CPVC was meeting the respondents' expectations with these same factors.

The survey indicated there is no difference in satisfaction level among preveterinary students and students of different academic standings. Focusing one or the other groups of students will not increase the overall satisfaction level. While the CPVC has received positive satisfaction rating for most aspects of the clinic; there is room for improvement. With 65 percent of students planning on attending veterinary medical school and additional 5 percent on becoming registered veterinary technicians, increasing the level of student satisfaction of veterinary skill development is recommended. The CPVC already offers a technical veterinary skills course (ASCI 310 ) to students, but only 34 percent of respondents have taken or are currently taking the course. By working with advisors and administration in the animal science department to increase enrollment in this course, the CPVC can boost satisfaction levels of students with regard to the veterinary skill development. 
The data shows that 95 percent of respondents reported hands-on learning to be a strength of the CPVC. While rated extremely satisfied by respondents, it is not surprising that hands- on learning is also the greatest strength of the clinic. Practical animal exposure, veterinary knowledge, veterinary technician skill development, and class size followed in terms of strengths at the CPVC. Of all the possible strength offered to the respondents, medical case diversity and student mangers knowledge were not a great strength of the CPVC.

Continuing to use hands-on learning experiences as the primary teaching method will be highly beneficial to the clinic. The CPVC should continue to host laboratories and other teaching courses at the CPVC to provide a continual flow of students interested in veterinary medicine through the clinic each quarter. Thus increasing the number of student participants who have experienced the hands- on learning environment the CPVC has to offer. In every aspect of the CPVC, the Cal Poly motto of "learn by doing" can be seen at the clinic.

The data also indicated 89 percent of respondents would like to see more diverse cases and animal treatment in the future. More diverse courses, more hands-on learning experiences, more opportunities to volunteer, and different veterinary skills were also changes respondents would like to see in the future for the CPVC. Both the results for the strengths and possible future changes coincide with each other indicating that students feel the CPVC is lacking in terms of diverse animal cases and would like to see that change in the future. 
Furthermore, this information could be useful when developing new curriculum for courses offered at the CPCV. The clinic could host a variety of animal medical specialists from the San Luis Obispo community to the CPVC including cardiologists, orthopedists, or nutrition specialist, in order for students to learn from these diverse topics of animal medicine. Additionally, this recommendation would also not take any clients away from veterinarians in the San Luis Obispo community, but instead strengthen a relationship between the university and community.

In order to have a better understanding of the value the CPVC has to offer the Cal Poly students, faculty and San Luis Obispo community a proposed mission statement for the Cal Poly Veterinary Clinic is as follows:

The Cal Poly Veterinary Clinic endeavors to teach its students to provide exceptional and compassionate animal healthcare in a "Learn By Doing" environment of expanding knowledge and discovery of all animals. The Cal Poly Veterinary Clinic strives to exceed the current and future needs of our clients, students, and veterinary healthcare team by providing the foremost in patient care, education, and preparation for graduate/ professional school or a career in veterinary medicine.

Conclusion

There has been a lack of research at the undergraduate level in regards to importance of hands- on practical learning experiences in agricultural departments. School administrations are responsible for the continual 
restructuring and refocusing of the animal science program, specially the preveterinary medical program, in order to supply students with the relevant skilled required by future employers. This research is important to the Animal Science Department at Cal Poly, as well as department faculty of other hands- on learning departments.

From this research, the Cal Poly Animal Science Department faculty can have better knowledge and understanding of what specific areas of the CPVC should focus on. For example, focusing on small animal medicine or offering opportunities for students to part take in anesthetic surgery on campus animals would be ideal for the clinic. The university faculty will also have a better understanding of the strengths of the clinic and improvements needed at the clinic. While the CPVC is a full functioning veterinary clinic, its mains purpose is to teach the animal science students about veterinary medicine through handson practical experiences. Since the CPVC is a student run clinic where students and veterinarians are teaching other students about veterinary medicine understanding the students' perceptions of the clinic is very important to the success of the clinic; academically and professionally. Additionally, from this research, the faculty is able to learn which aspects of the veterinary clinic do current and past students feel are most important and their satisfaction levels of these different aspects.

\section{Recommendations}

For others looking to expand on this research or perform a similar study, there are a few different areas where it would be beneficial to collect more data. 
The survey results indicated that over 90 percent of respondents felt that hands- on learning experiences at the CPVC are extremely important, but there was no research into what type of activities would be seen as hands- on learning experiences compared to ones already instituted at the facility. It would be interesting to further study the different type of activities and determine which ones are valued most by Cal Poly students participating at the CPVC.

It is also recommended for future research to survey the general population of the Cal Poly students, faculty, and the community of San Luis Obispo for a greater understanding of their knowledge of the CPVC. The CPVC can then use this information to develop business strategies to better meets the needs of the Cal Poly and San Luis Obispo community. Also surveying a greater variety of agricultural student will broaden the scoop of the research as well.

The survey indicated that 65 percent of respondents plan on attending veterinary medical school after graduation from Cal Poly. It would be interesting to further the study by following up with students who participated at the CPVC during their college education at Cal Poly and see how the CPVC prepared the students for success in veterinary medical school. The CPVC could then use this information to determine what specific experiences and skills should be taught at the CPVC to better prepare the students for a career in veterinary medicine. 


\section{REFERENCES}

Aldrich, G.,\& Irlbeck, N.A. (2008). "Animal Science Perception of Companion Animals Survey" Pet Food \& Ingredient Technology Inc., Topeka, KS.

Barrows, H., and Tamblyn, R. Problem-based Learning: An Approach to Medical Education. New York: Springer, 1980.

Bowden, S. (2003). Practice placements for undergraduate veterinary nurses. In Practice, 25(4), 227-229.

Britt, J., Aberle, E., Esbenshade, K., \& Males, J. (2008). Animal science departments of the future. Journal of Animal Science. 86(11), 32-35.

Buchanan, D.S., Hibberd, C.A., Kropp, J.R., \& Damron, W.S. (1994). Revision of the animal science curriculum: responding to students, industry changes and evolving university guidelines. NACTA Journal, 38(2), 9-14

Elmore, R.G. (2003). Recruitment and retention of veterinary students for food animal practices. Jour. Am. Vet. Med. Assoc., 222(12), 1697-1699.

Ellaway, R., Dewhurst, D., \& Cumming, A. (2003). Managing and supporting medical education with a virtual learning environment: The Edinburgh electronic medical curriculum. Medical Teacher, 25 (4)

Gaspard, M., Burnett, M. \& Gaspard, C. (2011). The influence of self-esteem and selected demographic characteristics on first semester academic achievement of students enrolled in a college of agriculture. Journal of Agricultural Education, 52(4), 76-86. 
Ghosh, I.K., (2013). Learning by doing models to each undergraduate economics. Journal of Economics and Economic Education Research, 14(1), 105-119

Howard, N., \& Strauss, W. (2000). Millennials Rising: The Next Generation.

Jelinski, M.D., Campbell, J.R., \& Miller, L.M. (2008). Demographics and career path choices of graduates from three Canadian veterinary colleges. The Canadian Veterinary Journal. 49 (10). 995-1001.

Love, G.M., \& Yonder, E.P. (1989). An assessment of undergraduate education in American colleges of agriculture. State College, PA: Pennsylvania State University, College of Agriculture.

Lynch, R. L. (2000). High school career and technical education for the first decade of the 21st century [Electronic version]. Journal of Vocational Education Research, 25(2), 1-20.

Mankin, K., Boone, K., Flares, S., \& Willyard, M. (2004). What agriculture students say motivates them to learn. NACT Journal, 48(4), 6-11.

Martin A. O'Neill, Adrian Palmer. Importance-performance analysis: a useful tool for directing continuous quality improvement in higher education. Qual Assur Educ, 12 (1) (2004), pp. 39-52

Mills, P. (2003). Group project work with undergraduate veterinary science students. Assessment and Evaluation in Higher Education, 28(5), 527538. 
National Center for Education Statistics. (NCES).(2011).

Noel, J. \& Qenani, E. (2013) New age, new learners, new skills: What skills do agribusiness graduates need to succeed in the knowledge economy? International Food and Agribusiness Management Review. 16(3), 17-35.

Peffer, P.A.L. (2011). Demographics of an undergraduate animal sciences course and the influence of gender and major on course performance. NACTA Journal, 55(1), 26-31.

Purdie, J., Williams, J., \& Ellersieck, M. (2007). The effect of participating in a pre-veterinary learning community of freshmen interest groups (fig) on the odds of new animal science majors graduate. Journal of Agricultural Education, 48(2), 46-55.

Radford, A., Stockely, P., Taylor, I., Turner, R., Gaskell, C., et al. (2003). Use of simulated clients in training veterinary undergraduates in communication skills. The Veterinary Record. 152(14), 422.

Robert L. Rhykerd, Kerry W. Tudor, and Bryon R. Wiegand. (2006). Enhancing experimental learning through a Hands-on Crop Production and Marketing Contest. NACTA Journal. 50 (4). 25-30.

Sandmaung, M., \& Khang, D. (2013). Quality expectations in higher education institutions: multiple stakeholder perspectives. Quality Assurance in Education, 21(3), 260-281. 
Savage, R., Chen, K., Vanasupa, L. et al. (2009). Integrating project-based learning throughout the undergraduate engineering curriculum. IEEE Engineering Management Review, 33(1), 25.

Sheahan, P. (2005). Generation Y: Thriving and surviving with generation $Y$ at work.

Slusher, W., Robinson, J., \& Edwards, M. (2010) Animal science experts' opinions on the non-techinical skills secondary agricultural education graduates need for employement in the animal science industry: a dalphi study. Journal of Career and Technical Education, 25(1), 8-20.

Spreng, R. A., \& Mackoy, R. D. (1996). An empirical examination of a model of perceived service quality and satisfaction. Journal of retailing, 72(2), 201214.

Stewart, V., S. Marsh, R. Kingwell, D. Pannell, A. Abadi, and S. Schilizzi. 2000. Computer games and fun in farming-systems education?: A case study. Journal of Agricultural Education and Extension, 7(2), 117- 128.

Sung, Y., Turner, S. \& Kaewchinda, M. (2013). Career development skills, outcomes, and hope among college students. Journal of Career Development. 40(2), 127-145.

Telg, R., \& Irani, T. (2005). Integrating critical thinking into agricultural communications curricula. Journal of Applied Commination. 89 (3), 13-21. 
United States. Bureau of the Census. (1975). Historical statistics of the United States, colonial times to 1970 (No. 93). US Department of Commerce, Bureau of the Census.

World Book. (2002). 


\section{APPENDIX}

Appendix 1: Survey

\section{Introduction}

Dear Student:

$\mathrm{H}$ ! My name is Fallon Sheridan and I am a graduate student in the Agribusiness Department at Cal Poly I have been working with the Animal Science Department and Dr. Sprayberry on assessing the contributions the Cal Poly Veterinary Clinic provides its students in preparation for a career in agriculture and veterinary medicine. You are being contacted because you are currently taking a course located at the Cal Poly Veterinary Clinic or you have taken a course in the past.

Your participation in this survey is vital to the success of our efforts in improving this facility.

To participate in the survey, please click the link below.

https://www.surveymonkey.com/s/SQZFDDL

Should you have any concerns, please contact fbsheridan@gmail.com.

All information that you provide is anonymous.

I greatly appreciate you taking the time to participate in this important research for the Cal Poly Veterinary Clinic.

Respectfully,

Fallon Sheridan 


\title{
Survey
}

\section{CAL POLY VETERINARY CLINIC QUESTIONNAIRE}

\author{
INFORMED CONSENT TO PARTICIPATE IN A RESEARCH PROJECT “THE \\ CONTRIBUTIONS THE CAL POLY SLO VETERINARY CLINIC PROVIDES AGRICULTURAL \\ STUDENTS IN CAREER PREPARATION."
}

A research project on The Cal Poly SLO Veterinary Clinic is being conducted by Fallon Sheridan and Dr. Michael McCullough in the Department of Agribusiness at Cal Poly, San Luis Obispo, CA.

The purpose of the study is to assess the contributions the California Polytechnic State University, SLO Veterinary Clinic provides agricultural students in preparation for a career in agricultural and veterinary medicine. This study will also explore the expectations of the students participating at the Cal Poly Veterinary Clinic.

You are being asked to take part in this study by filling out the following survey. Your participation will take approximately 10 to 15 minutes. Please be aware that you are not required to participate in this research and you may discontinue your participation at any time without penalty. You also do no thave to answer any questions you choose not to answer.

Your anonymity will be protected as no questions on the survey ask for personal information or business identity. The intent of the survey is to gather information on the California Polytechnic State University, SLO Veterinary Clinic. The information gathered from those that take the survey will be placed in a database and aggregate statistical analysis will be done. The results of the statistical analysis will be used to determine the importance of the Veterinary Clinic on the campus of Cal Poly, SLO.

If you have questions regarding this study or would like to be informed of the results when the study is completed, please feel free to contact Fallon Sheridan at fbsheridan@ gmail.com or Dr. Michael McCullough (805-756-5009).

If you have concerns regarding the manner in which the study is conducted, you may contact Dr. Steve Davis, Chair of the Cal Poly Human Subjects Committee, at 805-756-2754, sdavis@calpoly.edu, or Dr. Dean Wendt, interim Dean of Research, at 805-756-1508, dwendt@calpoly.edu.

If you agree to voluntarily participate in this research project as described please indicate you agreement by completing the questionnaire. Please print copy of this consent form now for your reference and thank you for participating in this research.

\section{What is you gender?}

j Im Male 
j Im Female

3. What is your academic standing?
$\mathrm{nl}$ j Freshman
ml j Sophomore
$m l$ j Junior
$\mathrm{ml} \mathrm{j}$ Senior
$\mathrm{ml}$ j Graduate Student

4. Where do you currently live?
l j On Campus
$\mathrm{nl} \mathrm{j} \mathrm{Off} \mathrm{Campus}$

5. How do you pay for your college education? Please choose all that apply.
$c$ ef Personal Funds
c ef Family/ Private Funds
c ef Financial Aid
c ef Scholarships

6. Is your family involved in agriculture? Please choose all that apply.
e c Farmers/ Ranchers
e c Agricultural Educators
e c State Representatives
e c Veterinary Medicine
e c Not involved in agriculture

\section{Do you or your family own pets?}
j Im Yes
j Im No

\section{What is your major?}
$\mathrm{ml}$ j Animal Science
ml j Dairy Science
$\mathrm{ml}$ j Agricultural Science
$\mathrm{nl}$ j Agribusiness 

ml j Agricultural Systems Management
$\mathrm{ml}$ j Food Science

Other (please specify)

\section{Are you a Pre -Veterinary undergraduate student?}

$$
\begin{aligned}
& \text { j Im Yes } \\
& \text { j Im No }
\end{aligned}
$$

10. Do you plan on attending any of the following programs after graduation?

\footnotetext{
ml j Veterinary Medical School

j Im Master Graduate Programs

j Im Doctoral Programs (other than Veterinary Medicine)

j Im Registered Veterinary Technician Programs

$\mathrm{ml}$ j Not planning on attending any program after graduation
}

11. How have you been involved at Cal Poly Veterinary Clinic? Please choose all that apply.
e c Enterprise Course (ASCI 290)
c ef Companion Animal Science Course (ASCI 227)
c ef Technical Veterinary Skills Course (ASCI 310)
C ef Anatomy \& Physiology of Farm Animals (ASCl 229)
C ef Systemic Animal Physiology (ASCl 438)
c ef Student Lab Teacher
c ef Volunteer
Other (please specify)

12. On average how many hours per week do or did you spend at Cal Poly Veterinary Clinic?
$\mathrm{ml} \mathrm{j} \mathrm{0-2.0} \mathrm{hrs}$
$\mathrm{ml}$ j 2.1-4.0 hrs
$\mathrm{ml} \mathrm{j} 4.1-6.0 \mathrm{hrs}$ 

$\mathrm{ml} \mathrm{j} 6.1-8.0 \mathrm{hrs}$
$\mathrm{ml} \mathrm{j} 8.1-10.0 \mathrm{hrs}$
nl j 10.1+ hours

13. How many quarters have you been involved with Cal Poly Veterinary Clinic? (including this quarter)

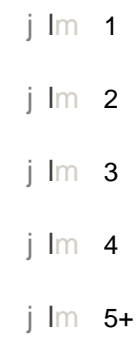

14. In a short paragraph, explain how the Cal Poly Veterinary Clinic is meeting your expectations.

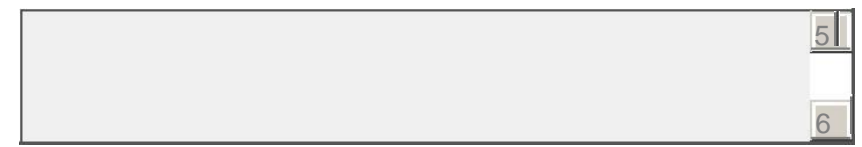

15. Rate the following statement: "The Cal Poly Veterinary Clinic hands -on learning environment is preparing me for my future educational goals."
ml j Strongly Agree
ml j Agree
ml j Neutral
ml j Disagree
ml j Strongly Disagree

16. Rate the following statement: "The hands -on experience at the Cal Poly Veterinary Clinic has met my expectations for the clinic."
$\mathrm{ml}$ j Strongly Agree
ml j Agree
ml j Neutral
ml j Disagree
ml j Strongly Disagree 
17. The following is a list of benefits student may look for when participating at the Cal Poly Veterinary Clinic. Indicate the importance of each benefit to you when participating at the on campus clinic. Extremely Important, Very Important, Somewhat Important, Slightly Important, Not At All Important

\begin{tabular}{|l|l|l|l|l|l|}
\hline & $\begin{array}{l}\text { Extremely } \\
\text { Important }\end{array}$ & $\begin{array}{l}\text { Very } \\
\text { Important }\end{array}$ & $\begin{array}{l}\text { Somewhat } \\
\text { Important }\end{array}$ & $\begin{array}{l}\text { Slightly } \\
\text { Important }\end{array}$ & $\begin{array}{l}\text { Not At All } \\
\text { Important }\end{array}$ \\
\hline Hands-on Learning & & & & & \\
\hline Resume Building & & & & & \\
\hline Practical Animal Exposure & & & & & \\
\hline $\begin{array}{l}\text { Preparation for Veterinary } \\
\text { Medical School }\end{array}$ & & & & & \\
\hline $\begin{array}{l}\text { Veterinary Technician Skill } \\
\text { Development }\end{array}$ & & & & & \\
\hline Teaching Methods & & & & & \\
\hline Veterinarians & & & & & \\
\hline Student Managers & & & & & \\
\hline
\end{tabular}

18. The following is a list of factors students may find satisfying when participating at the Cal Poly Veterinary Clinic. Indicate your level of satisfaction of each factor to you when participating at the campus clinic. Extremely Satisfied, Very Satisfied, Somewhat Satisfied, Slightly Satisfied, Not Satisfied At All.

\begin{tabular}{|l|l|l|l|l|l|}
\hline & $\begin{array}{l}\text { Extremely } \\
\text { Satisfied }\end{array}$ & $\begin{array}{l}\text { Very } \\
\text { Satisfied }\end{array}$ & $\begin{array}{l}\text { Somewhat } \\
\text { Satisfied }\end{array}$ & $\begin{array}{l}\text { Slightly } \\
\text { Satisfied }\end{array}$ & $\begin{array}{l}\text { Not Satisfied } \\
\text { At All }\end{array}$ \\
\hline Hands-on Learning & & & & & \\
\hline Resume Building & & & & & \\
\hline Practical Animal Exposure & & & & & \\
\hline $\begin{array}{l}\text { Preparation for Veterinary } \\
\text { Medical School }\end{array}$ & & & & & \\
\hline $\begin{array}{l}\text { Veterinary Technician Skill } \\
\text { Development }\end{array}$ & & & & & \\
\hline Teaching Methods & & & & & \\
\hline Veterinarians & & & & & \\
\hline Student Managers & & & & & \\
\hline
\end{tabular}

19. Please rank the following clinical experiences in order of preference. ( 1 being the most likely to participate, and 10 being the least likely)

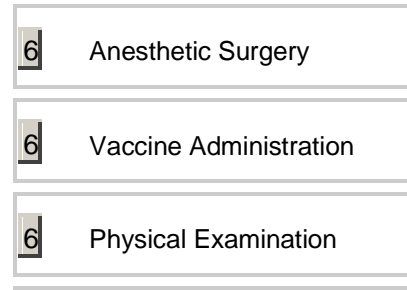




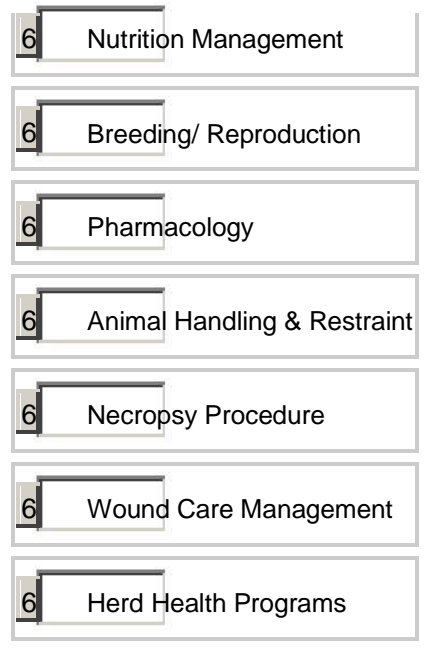

20. Please rank the following species in order of preference for a career in veterinary medicine. ( 1 being the most interested, and 11 being the least interested species)

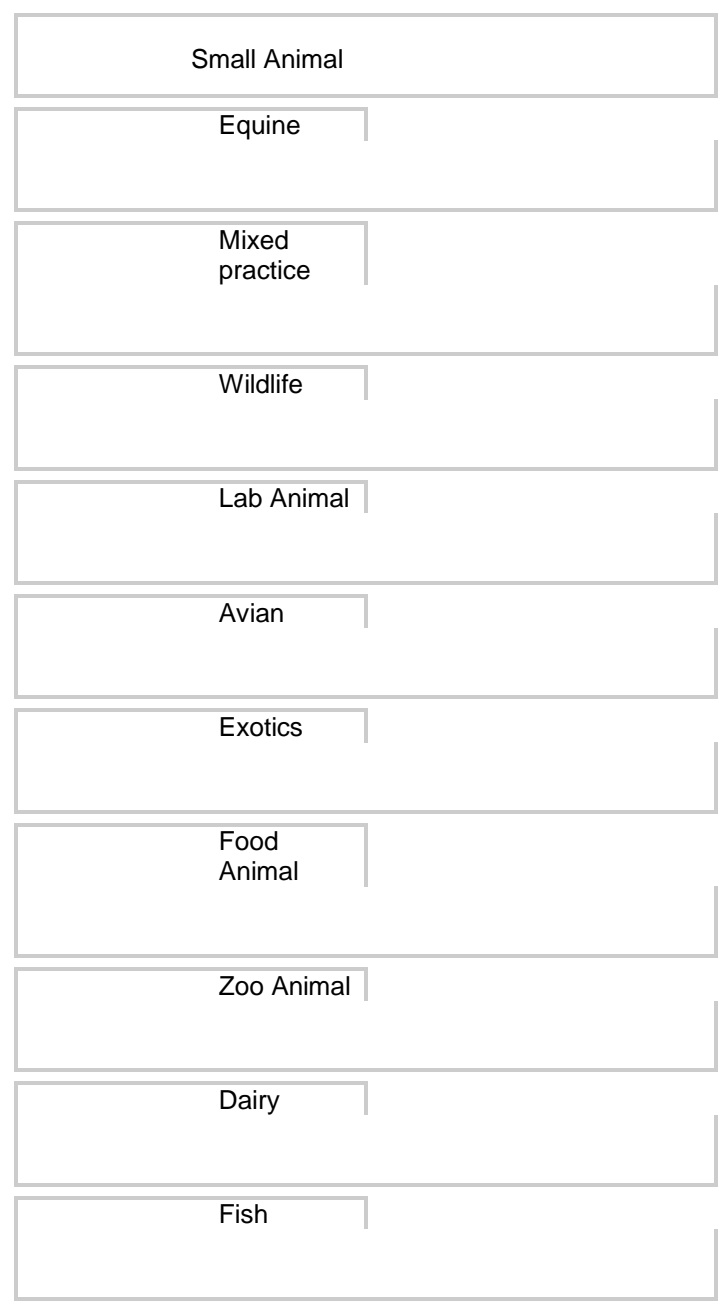


21. How likely are you to recommend the Cal Poly Veterinary Clinic to other students?
ml j Extremely Likely
ml j Very Likely
ml j Moderately Likely
ml j Slightly Likely
$\mathrm{ml}$ j Not at all Likely

22. What are the strengths of the Cal Poly Veterinary Clinic? Please choose all that apply.
e c Hands-on Learning
c ef Practical Animal Exposure
c ef Veterinary Technician Skill Development
c ef Veterinary Knowledge
c ef Student Managers Knowledge
c ef Class Size
fe c Medical Case Diversity

\section{In the future, what changes would you like to see at the Cal Poly} Veterinary Clinic? Please choose all that apply.
fe c More diverse courses offered at the clinic
c ef Different veterinary skills
c ef More hands-on learning experiences
C ef More diverse cases/ animal treatments
c ef More opportunities to volunteer
$c$ ef More emphasis on business management
c ef None-it's perfect the way it is

Other (please specify) 